\title{
Late Paleozoic-Mesozoic tectonic evolution of SW Japan: a review - Reappraisal of the accretionary orogeny and revalidation of the collisional model
}

\author{
Jacques Charvet
}

Institut des Sciences de la Terre d'Orléans (ISTO), UMR 6113, 1A rue de la Férollerie, 45100 Orléans, France

E-mail address: jacques.charvet@univ-orleans.fr

\section{Abstract}

This paper makes a review of the interpretations of the tectonic evolution of SW Japan during the last three decades. In the late 1970s, the dominant model was the so-called "Pacific-type orogeny", emphasizing the purported absence of nappes and the contrast with the alpine chains, and interpreting the evolution as due to a steady oceanic subduction since the Paleozoic time. In the 80 s, the discovery of the actual structure made of a pile of large thrust sheets led authors to propose collisional models, involving the intermittent underthrusting of buoyant blocks like micro-continents. At the same time, the use of highresolution biostratigraphy allowed several authors to recognize ancient accretionary wedges, with a reconstructed ocean plate stratigraphy of individual accreted units, especially in the Tanba and Shimanto zones. Also, precise radiometric dating permitted the distinction of metamorphosed units, especially in Sanbagawa and Shimanto belts. As a result of these new data, since the 1990s, the plate tectonic interpretation of the history of the Japanese islands was revised by Japanese scientists and presented again in terms of accretionary processes linked to a steadily oceanic subduction, with an episodic ridge subduction: the so-called "Miyashiro-type orogeny". The review of different data leads to the following conclusions. The structure of SW Japan is made of a pile of sub-horizontal nappes, polydeformed, with a geometry similar to the one encountered in collisional orogens. The geodynamic mechanisms advocated for the tectonic building within the accretionary orogeny concept (Miyashiro-type orogeny) are inappropriate. A permanent oceanic subduction with the intermittent "collision" (actually subduction) of an active ridge or seamount chain is unable to build such structures, as this process induces in fact an acceleration of the tectonic erosion and collapse of the upper plate; the underthrusting of a micro-continent or mature arc is likely needed. The exhumation story of Sanbagawa HP schists suggests the setting of a continental subduction. The petrological and new geochemical data from the literature strongly support the existence, 
beneath the nappes of accretionary complexes, of continental bodies showing affinities with South China, from which they were once separated. The episodic collision, underthrusting, of such blocks was responsible for the tectonic piling. Tectonic erosion plaid likely a major role in removing material during the intervening subduction stages. A revised geodynamic model, implying the collision of the Honshu, South Kitakami-Kurosegawa, and Shimanto Blocks, is proposed for explaining the three orogenic crises which took place respectively at around 240, 130, and 80-60 Ma ago in SW Japan. The paleogeographic position and affinity of the Hida block with surrounding units, in the hinterland, are still unclear. More work is needed to solve this question.

Key words: Japanese Islands, collisional orogen/accretionary orogen, Late Paleozoic, Mesozoic, tectonics, geodynamics

\section{Introduction}

The Japanese Islands are often considered as a typical example of accretionary orogen (e.g. Cawood et al., 2009), built during the subduction of an oceanic plate, by superimposition of accretionary wedges composed of material coming from the upper plate by erosion and mainly from the downgoing plate (accretion $s$. st.), including deep-sea sediments, oceanic plateaus, HP metamorphic rocks. Due to this process, the upper plate is growing ocean-ward, and some syn- to post-orogenic granitoids are emplaced, initiated by melting of the lower plate crust and/or mantle wedge. The dominant model expressed today in the literature presents the Japanese Islands as a segment of subduction-related orogen built along the western Pacific margin, since at least the Mesozoic, by successive underthrusting of tectonic units corresponding to accretionary complexes, either sedimentary or affected by high P/T metamorphism (e.g. Isozaki, 1996, 1997; Maruyama, 1997; Isozaki et al., 2010). The episodicity of orogeny and production of granites is now assigned to the intermittent subduction of an oceanic ridge, core of the "Miyashiro-type orogeny" concept (Maruyama, 1997). A similar concept of subduction-related orogeny, piling Permian to Recent accretionary complexes, corresponds to the "Nipponides" of Sengör and Natal'in (1996). Basically, this interpretation is quite similar to the theory of "Pacific-type orogeny" (Matsuda and Uyeda, 1971), which was dominant in the 1970s. This model emphasized the role of paired metamorphic belts and insisted on one structural point: the assumed total absence of 
nappes in Japan and, due to this lack, the strong contrast with the Alpine chains. Therefore, in parallel with the development of the plate tectonic theory and the discovery of the great importance of subduction processes, an extrapolation of the present situation was made in the past; the Japanese Islands were considered as a permanent island-arc and a giant accretionary prism due to a steady oceanic subduction from Paleozoic to Present.

However, during the last 40 years, the interpretations and concepts related to the tectonic evolution of the Japanese Islands have evolved a lot and other models have been advocated.

During the 1980s, alternative collisional models were proposed, taking into account the new structural figure of SW Japan, after the discovery of large thrust sheets (e.g. Charvet et al., 1985; Faure et al., 1986). In this interpretation, the episodic orogenic events are assigned to the intermittent arrival at the trench of a buoyant feature, micro-continent or mature arc, choking the subduction and inducing the piling of nappes which show a geometry similar to the one visible in classical collisional orogens. Similar collisional episodes were proposed for NE Japan (Komatsu et al., 1983; Jolivet, 1986; Jolivet et al., 1987; Kimura, 1997).

The aim of this paper is to review, based on a brief historical perspective, the validity of the main tectonic and geodynamic concepts implied by the two opposite models, when compared with the recent data. I will show that the pure accretionary model is likely invalid and that the collision of light blocks is the only mechanism able to account for the different data: tectonic, geodynamic, petrologic, and geochemical. A new geodynamic model, taking into account those recent data coming from the literature, is proposed at the end. Although this reflecting is valid for the whole Japan and different tectonic events, I will restrict my point to SW Japan, to the SW of the Itoigawa-Shizuoka fault (Fig. 1) and mainly to the tectonic development from Late Paleozoic to Paleocene.

\section{The discovery of nappes: invalidity of the Pacific-type orogeny, proposal of the collisional model}

As mentioned before, the theory of "Pacific-type orogeny" (Matsuda and Uyeda, 1971) was dominant in the 1970s. This model emphasized the role of paired metamorphic belts (Miyashiro, 1961) and the assumed total absence of nappes in Japan and, due to this 
lack, the strong contrast with the Alpine chains. Although the concept of paired metamorphic belts can be discussed and questioned (e.g. Brown, 1998, 2010), this point will not be addressed in detail here and treated only incidentally; I will concentrate on the tectonic and geodynamic aspects.

In the 1970s, the geometry of structures was poorly known and the stack of nappes ignored, despite some previous works advocating their existence (e.g. Fujimoto, 1937). However, in the late 1970s and early 1980s, two developments induced a big change in the understanding of the geometry of the different units, leading to the recognition of the structural scheme admitted today (Fig. 2). The first one was a revolution in the Japanese stratigraphy, due to the use of conodont and radiolarian faunas. The second one was the input of modern structural studies, by Japanese and foreign scientists, in particular the French team with an experience of alpine belts. The dating by conodonts and radiolaria showed that some formations, previously considered as Permian in the Inner zones of SW Japan, are in fact Triassic-Jurassic olistostromes and, due to the geometric superimposition of unambiguous Paleozoic units, should be interpreted as tectonic windows (Hayasaka and Hara, 1982; Faure and Caridroit, 1983). The general presence of thrust sheets and nappes in all the zones (e.g. Charvet, 1980; Faure, 1983; Charvet et al., 1983; Faure and Charvet, 1983, 1984; Guidi et al., 1983; Caridroit et al., 1985) led to the recognition of an "Alpine-type orogen in an island-arc position" (Charvet et al., 1985). Since then, the structural sketch of SW Japan was changed and considered as a piling of nappes (Fig. 1,2) built by some specific orogenic events.

Those major tectonic events, responsible for the Triassic, Cretaceous, Eocene, and Miocene thrustings, were interpreted in terms of collisional tectonics, the subduction leading to the episodic arrival of buoyant micro-continents in the subduction zones (Charvet and Faure, 1984; Faure and Charvet, 1984, 1987; Charvet et al., 1985, Faure et al., 1987; Caridroit et al. 1987). Some variations were suggested. For instance, regarding the Permian-Triassic belt of Inner Japan, the limestone Oga nappe, overriding the Sangun HP schists and Yakuno ophiolites, initially interpreted as a former seamount of the subducting ocean (Caridroit et al., 1987; Faure and Charvet, 1987), was later proposed to be a part of the Hida-Sino-Korean margin (Cluzel, 1991; Chough et al. 2000). 


\section{Recent interpretations: recognition of large thrust sheets but return to the accretionary model with ridge subduction}

The existence of nappes is widely admitted nowadays by the Japanese geological community. The advocated allochthony is even larger than previously proposed. For instance, if the North Chichibu zone was recognized as a klippe thrust over the Sanbagawa schists and rooted in the Tanba zone (e.g. Faure and Charvet, 1987; Kawato et al., 1991) (Kumoso locality, Fig. 3), the klippe system is now considered as including the South Chichibu (Sanbosan) and the composite Kurosegawa terrane, which comprises old (pre-Silurian to Siluro-Devonian) rocks (Yoshikura et al., 1990; Aitchison et al., 1991, 1996; Hada et al., 2000) and a serpentinous mélange (Isozaki and Itaya, 1991; Isozaki, 1996, 1997). And the Kurosegawa terrane, formerly regarded as a part of the colliding block acting as the relative autochthon of the overthrust Sanbagawa HP schists unit (e.g. Maruyama et al., 1984), from southern origin (Aitchison et al., 1991; Hada et al., 2001), is now seen as a mélange coming from the innermost zones (Isozaki, 1997; Maruyama, 1997; Isozaki et al., 2010). Also, the Sanbagawa zone was demonstrated to overthrust directly the Cretaceous North Shimanto zone in central Kii peninsula (Sasaki and Isozaki, 1992; Masago et al., 2005). And, in Oboke area, central Shikoku, the lower unit made of Koboke and Kawaguchi Formations, initially regarded as a psammitic schists unit of the HP belt, appears to be a tectonic window correlated to North Shimanto; the protolith of those formations is younger than ca. 92-82 Ma, and the metamorphic age around $60 \mathrm{Ma}$, whereas the protolith of Sanbagawa schists is older than $130 \mathrm{Ma}$ and the metamorphic age around 120-110 Ma (Aoki et al. 2007, 2008; Isozaki et al., 2010, and ref. therein) or 89-88 Ma (Wallis et al, 2009).

But, if the bulk geometry of flat-lying thrust sheets of different ages is widely accepted, and supported by seismic records (Kawamura et al., 2003; Ito et al., 2009), the interpretation in terms of collisional orogeny is usually abandoned, at least for the postTriassic events, to the benefit of the accretionary orogeny model. The whole SW Japan is considered as a pile of accretionary complexes younging downward (Fig. 4).

Indeed, since the 1980s, the use of high-resolution biostratigraphy (conodonts and radiolaria) allowed several authors to recognize ancient accretionary wedges, with a reconstructed ocean plate stratigraphy of individual accreted units, especially in the Tanba and Shimanto zones (e.g. Matsuda and Isozaki, 1991; Matsuoka, 1992; Isozaki, 1996, 1997; 
Wakita, 2000; Wakita and Metcalfe, 2005; Isozaki et al., 2010, and ref. therein). Also, precise radiometric dating permitted the distinction of metamorphosed units, especially in Sanbagawa and Shimanto belts (e.g. Suzuki et al., 1990; Isozaki and Itaya, 1991; Aoki et al., 2008, and ref. therein).

As a result of these new data, in the 1990s, the plate tectonic interpretation of the history of the Japanese islands was revised by Japanese scientists in terms of accretionary processes linked to a steadily oceanic subduction, with an episodic ridge subduction assumed to be responsible for the genesis of metamorphic-granite belts (e.g. Isozaki, 1996, 1997; Maruyama, 1997; Isozaki et al., 2010).

The progress in understanding and modeling the exhumation of HP metamorphic rocks, associated with precise field survey of the contacts led authors to re-interpret the Sanbagawa belt in terms of a thin accretionary slice formed along the subduction channel and emplaced by wedge extrusion (Maruyama et al., 1996; Ota et al., 2004; Masago et al., 2005; Osozawa and Pavlis, 2007; Aoki et al., 2008) or another process (Mori and Wallis, 2010). A particular attention has been given to the eclogites of central Shikoku, interpreted as an oceanic plateau in an accretionary complex (Terabayashi et al., 2005) or derived from an oceanic island arc (Utsunomiya et al., 2011), and to their metamorphic conditions reaching locally 2.5 to more than $3 \mathrm{GPa}$ and $900^{\circ} \mathrm{C}$ (Enami and Miyamoto, 2001; Ota et al., 2004). They have undergone two metamorphic stages (Endo, 2010): a first one at around $120 \mathrm{Ma}$, the last one, eclogitic, at 89-88 Ma, followed by a fast exhumation, with a rate of $2.5 \mathrm{~cm} / \mathrm{a}$ (Wallis et al., 2009).

Between $500 \mathrm{Ma}$ and the Tertiary, five major orogenies occurred (Isozaki et al., 2010), respectively at: $450 \mathrm{Ma}$ (Oeyama), $340 \mathrm{Ma}$ (Renge), $240 \mathrm{Ma}$ (Akiyoshi), 140-130 and 80-60 Ma. This paper is dealing essentially with the period from the late Paleozoic to latest Mesozoic-early Tertiary, during which three main tectonic events occurred.

The late Permian-Triassic one is sealed by the Upper Triassic molasse. It involved the emplacement of the Yakuno ophiolite, the ca. 240 Ma old Suo HP metamorphic rocks (part of the previous Sangun schists now subdivided into a ca. 340 Ma Renge belt and the Suo belt), and HT metamorphism in Hida-Oki belt. Explicitly or implicitly, a collisional process is advocated for the Triassic event, either by correlation with the Qinling-Dabie-Sulu suture 
(Oh, 2006; Isozaki et al., 2010) or due the collision of a Proto-Japan block with the Asian margin (de Jong et al., 2009).

The Early Cretaceous event, post-dated by Cretaceous basins and by the Ryoke HT metamorphism, involved the remobilization of the Triassic belt, the piling and folding of Mino-Tanba and Chichibu units. The Late Cretaceous-Paleocene event, before the deposition of the Eocene Kuma Group, induced the reworking of the Early Cretaceous belt in the thrust system (final emplacement of Chichibu-Kurosegawa klippe), the HP metamorphism of North Shimanto and Oboke schists, the exhumation of Sanbagawa blueschists and eclogites. Those two Mesozoic tectonic events are now generally seen as successive accretions due to oceanic subduction, except some authors advocating the collision with micro-continents (e.g. Otsuki, 1992). This accretionary orogen model, also called "Misyashiro-type orogeny" (Maruyama, 1997) emphasizes the role of continuous oceanic and episodic ridge subduction.

\section{Invalidity of the accretionary orogeny: revalidation of the collisional model}

However, several facts are hardly explained by an ordinary oceanic plate subduction. Several lines of evidence contradict this interpretation: the geometry of structures, the comparison with the geodynamic processes presently working around the world, and the geochemical evidence.

\subsection{Tectonic considerations}

The bulk geometry, with flat and refolded thrust contacts, is different from an accretionary prism geometry. The reworking of older belts, in a kind of "basement nappes", implies huge deformation far beyond the back-stop. Even if it is assumed to be a simplified sketch, a cross-section like the one on Fig. 4 (after Isozaki et al., 2010) is misleading. The tectonic contacts between units have been refolded and reactivated, several times for some of them; for instance the Permian-Triassic stack has been thrust again at the end of Jurassic. The actual structure does not correspond to such an image of "in sequence" package but to a majority of "out-of-sequence" thrusts and cannot be compared with the classical anatomy of an accretionary prism. And the main contacts cannot be assigned to the former Wadat-Benioff planes. Actually the geometry, involving the multiple thrusting of ancient nappe systems, with different metamorphic evolution, recalls the one of classical collisional orogens. 
Nevertheless, the large allochthony advocated in some recent papers can be discussed. An example is given by the Kurosegawa rocks, presented as a pre-Jurassic klippe initially thrust over the Tanba-Chichibu units (Isozaki and Itaya, 1991; Isozaki et al, 2010) and therefore rooted to the west of Tanba or as olistoliths in such a far-travelled olistostrome klippe (Masago et al., 2005)(Fig. 5). The Kurosegawa terrane is agreed to be correlative with South Kitakami (Fig. 1), a large massif in NE Japan with old rocks (e.g. Ehiro, 2000). It is questionable that they both represent olistoliths coming from the innermost zones and reworked in a Mesozoic mélange; their affinity with Hida Gaien is debated. If they are nappes rooted near the Hida zone (Isozaki, 1997), that would strongly argue for a collisional model. But the South Kitakami massif is probably not a big thrust package coming from circum-Hida area; there is no structural evidence for that. An alternative and more likely interpretation is that the Kurosegawa zone, which records evidence of strike-slip faulting during the Early Cretaceous (Kato and Saka, 2003), could be originally the autochthonous basement of the Lower Cretaceous nappes, reworked as a klippe at the end of Cretaceous, together with Chichibu units. This two-stage interpretation is consistent with the fact that the initial strikeslip faults, active during the Early Cretaceous, are cut by the younger thrust contact (Butsuzo Tectonic Line) (Fig. 6) responsible for the tectonic superimposition of those units above the Upper Cretaceous Shimanto domain (Kato and Saka, 2003, 2006).

\subsection{Geodynamic implications}

Any interpretative theory of the tectonic development of Japan must comply with the global geodynamic machinery acting around the world. Several geodynamic processes advocated within the frame of the accretionary orogeny model look actually unable to build the described structures.

The first and main difficulty regards the ridge subduction, considered to be responsible for the episodic tectonic crises and nappe emplacement (Maruyama, 1997; Isozaki et al., 2010). The subduction of an active oceanic ridge, according to the presently working and well documented recent example, cannot explain the tectonic piling. Such a subduction actually induces an acceleration of the tectonic erosion (e.g. Berhman et al., 1994; Bourgois et al., 1996), a collapse of the upper plate, but not an ocean-ward nappe piling. 
The same observation is made regarding the subduction ("collision") of other oceanic asperities: aseismic ridges, plateaus, seamounts.

When the subduction of an aseismic ridge participates in the shallowing of the downgoing plate and increases the coupling, it induces also tectonic erosion (e.g. von Huene and Ranero, 2010 and ref. therein); it may induce the development or the activation of a foldand-thrust belt, but in the back-arc area, mainly verging continent-ward, as documented in the Andes (e.g. Schmitz, 1994; Hartley et al. 2000; McQuarrie and DeCelles, 2001; McQuarrie, 2002; Müller et al., 2002; Barke and Lamb, 2006; Espurt et al., 2007). The crustal shortening is due to the bending and underthrusting of the Brazilian craton (e.g. Lyon-Caen et al., 1985), and occurs in the hot, thin zone of lithospheric weakness behind the arc, expected focus of shortening during periods of increased compressive stress (Cawood et al., 2009). As noticed along the Americas, the subduction of ocean floor relief can uplift the land surface above the "colliding" feature, but the process also involves accelerated tectonic erosion (von Huene and Ranero, 2010). Along Peru, short-term uplift during the subduction ("collision") of the ocean relief was followed by subsidence, leading to formation of basins in the middle and upper slopes, and extensional deformation (Clift et al., 2003).

The sometimes advocated accretion of seamounts and/or plateaus, for instance the Carboniferous Akiyoshi-Sawadani seamount chain, the Permian Maizuru seamount swarm (Maruyama et al., 1997; Isozaki et al., 2010), or the Late Jurassic Mikabu plateau (Isozaki et al., 1990) and Sorachi plateau in Hokkaido (Kimura, 1997) is also unable to explain the development of nappes. It has been demonstrated in many active margins around the Pacific, and particularly near Japan, that the arrival of seamounts at the trench may induce some local and temporary disturbance, including some small thrusts in the lower slope, but that the seamounts are broken by trench-parallel extensional faults as they pass over the outer trench rise and that they finally subduct in the same way as the surrounding oceanic lithosphere, provoking a collapse of the upper plate (e.g. Fryer and Smoot, 1985; Fryer and Hussong, 1985; Kobayashi et al., 1987; Lallemand and Le Pichon, 1987; Cadet et al., 1987; Lallemand and Chamot-Rooke, 1987; Ballance et al., 1989; Gardner et al., 2001; Fisher et al., 2004; von Huene, 2008).

Similar conclusions can be drawn in the case of oceanic plateaus, if they do not show any buoyancy contrast. Conversely, if they are of great size and a bit buoyant, the disturbance at the surface is more obvious and they may develop a conspicuous coastal uplift, like the Yakutat Block in Alaska (Eberhart-Phillips et al., 2006; von Huene and Ranero, 2010). However, in the mantle, the Yakutat slab is subducting with the Pacific plate and is not 
moving independently as a truly distinct plate (Eberhart-Phillips et al., 2006). Seismic records show that it is subducting down to $140 \mathrm{~km}$, with a slab up to $600-1000 \mathrm{~km}$ long (EberhartPhillips et al., 2006; von Huene and Ranero, 2010). It is a composite oceanic and continental block of 15- to 20-km-thick crust (Fuis et al., 2008) and, due to its buoyancy, its relative resistance to subduction causes some deformation: the unsubducted crust becomes a foreland fold-and-thrust belt (Fuis et al., 2008; von Huene and Ranero, 2010). The buoyancy seems to be a critical factor. If we look at the oceanic plateaus produced by LIPs, having an anomalously thick crust but with a density close or identical to the normal oceanic crust, their arrival at the subduction trench does not induce a major accretion. Regarding the biggest plateau in the world, the Ontong Java Plateau, covering 1,900,000 $\mathrm{km}^{2}$ and having a crust as thick as $33 \mathrm{~km}$, only $20 \%$ of the crust are accreted above a thrust décollement, the lower $80 \%$ of the plateau crust are subducting (Mann and Taira, 2004). The Ontong Java PlateauSolomon island arc convergent zone is the only known example on Earth of active accretion of an oceanic plateau at subduction zone. This giant is exceptional and, due to its almost entire subduction, it can be concluded that in general oceanic plateaus are not significant contributors to the crustal growth of arcs, and therefore, to continental growth (Mann and Taira, 2004).

In contrast, the arrival at the trench of a rather small block with a lighter crust, and therefore positive buoyancy, like a mature arc or a micro-continent is able to induce a collision producing permanent compressive structures. A good and well-known example is provided by the Izu collision in Central Japan, even if the accretion is only partial and a part of the arc is subducting (Yamamoto et al., 2009). The thickness of continental crust exerts a major control on this phenomenon, if we consider that the arcs thinner than $25 \mathrm{~km}$ subduct and the Izu arc, 30-35 km thick, induces collisional structures (Yamamoto et al., 2009). A past arc accretion-collision with an active margin likely occurred at the northwestern corner of the Pacific about $55 \mathrm{Ma}$ ago, between the Kamchatka-Koryak margin and the Olyutorsky arc (Scholl, 2007).

In conclusion, assigning the tectonic development of SW Japan to the episodic subduction of oceanic features like active ridge, seamount chain, plateau, is not in agreement with the way plate tectonics is presently working. The creation of large permanent oceanward compressive structures needs the underthrusting of buoyant blocks. 


\subsection{Exhumation of Sanbagawa HP metamorphic rocks}

In their synthesis on the exhumation of oceanic blueschists and eclogites worldwide, Agard et al. (2009) made several statements: no exhumation is possible beyond a depth of $\sim 70 \mathrm{~km}$, corresponding to 2.0-2.3 GPa; the oceanic exhumation velocities for HP-LT oceanic rocks, whether sedimentary or crustal, are usually on the order of the mm/a (between 1 and 5 $\mathrm{mm} / \mathrm{a}$ ), whereas they are on the order of a few $\mathrm{cm} / \mathrm{a}$ in the case of continental subduction. There is a link between faster exhumation rates and continental subduction. The exhumation of oceanic crust is obtained only when serpentinites are present in the slab mantle. In the case of Sanbagawa schists, they are assigned to the type B protoliths (ocean-derived), as defined by Maruyama et al. (1996) and considered as exhumed during an oceanic subduction.

However, some peculiarities lead to question this interpretation, at least for the eclogitic units present in central Shikoku, corresponding to the second stage of HP metamorphism (Endo, 2010), dated at 89-88 Ma (Wallis et al., 2009). According to detailed structural studies, eclogitic bodies form a large coherent unit that overlies a non-eclogitic unit with a major tectonic boundary and forms an eclogitic nappe (Wallis and Aoya, 2000; Aoya, 2001).

Agard et al. (2009) already noticed that the P-T paths for Sanbagawa rather resemble those known in well established collisional cases "despite the lack of subsequent collision". If the peak metamorphism reached the pressure of more than $3 \mathrm{GPa}$ (Enami and Miyamoto, 2001; Ota et al., 2004), that would suggest a continental subduction, as well as the fast exhumation rate of $2.5 \mathrm{~cm} / \mathrm{a}$ advocated by Wallis et al. (2009). The peak pressure might be somehow overestimated when based on mantle-derived material, not implying that the crust reached that depth (Oberhänsli, person. com.) and a general metamorphism peak pressure of 1.5-1.9 GPa is more likely for the whole package of oligoclase-biotite schists, which reached eclogite facies at a depth of $48-60 \mathrm{~km}$ and were exhumed at an average rate of only $1 \mathrm{~mm} / \mathrm{a}$ if the peak metamorphism occurred at 120-110 Ma (Aoki et al. 2009). Such a figure would be compatible with an oceanic subduction.

But some specific features are unusual in such a setting. The quartz-eclogite of the Iratsu body contains omphacite with quartz lamellae, a feature common in UHP rocks (Ota et al., 2004), and this quartz-eclogite is sedimentary in origin (Takasu, 1989; Ota et al., 2004). Also the presence of the Higashi-Akaishi garnet-bearing ultramafic body (Mizukami and Wallis, 2005) is unique amongst purported oceanic subduction-type metamorphic belts 
(Hattori et al., 2010); such lenses are known in collisional orogens. This body represents a cumulate assemblage, maybe a root of an arc (Hattori et al., 2010) or the base of an oceanic plateau (Terabayashi et al., 2005) which has been subducted down to 100-120 km (Enami et al., 2004; Hattori et al., 2010). In front of those "anomalies", Ota et al. (2004) state that "the Sanbagawa belt is potentially the first example of a regional ultrahigh-P metamorphic belt in the Pacific-type orogens of the world, with a wide $\mathrm{P}$ range covering depths of subduction zone magmatism" and Hattori et al. (2010) assume the existence of "a rare example of oceanictype ultrahigh-pressure metamorphism". It seems more realistic to question the model and admit that, at least regarding the eclogitic nappe, the metamorphic conditions and the implied important depth reached during subduction are only compatible with a continental subduction. Regarding the exhumation rate, it has been recently debated (Aoki et al., 2009, 2010; Wallis et al., 2009; Wallis and Endo, 2010), interpreted as slow or rapid depending on the dating of the peak eclogitic metamorphism at 120-110 or 89-88 Ma. The latter hypothesis, which is supported by Lu-Hf data (Wallis et al., 2009) but also by zircon ages (Aoki et al., 2009), could imply a rapid exhumation (more than $2.5 \mathrm{~cm} / \mathrm{a}$ ) for at least some units and a short-lived Sanbagawa orogeny, on time scales of a few million years (Wallis et al., 2009; Wallis and Endo, 2010). That would clearly add another evidence of a continental subduction setting for this exhumation.

In addition, it is worth noting that the protolith of the quartz-bearing eclogite was a sedimentary rock containing detrital zircons with a core as old as around $1900 \mathrm{Ma}$ (Okamoto et al., 2004). This fact has strong implications. Either the protolith was initially deposited near an arc (e.g. Utsunomiya et al., 2011) or a plateau (e.g. Terabayshi et al., 2005) on the oceanic bottom, before entering the subduction zone, and that means that this relief had a continental basement. Or, it was part of the accretionary prism and that implies the existence of an available Proterozoic source in Proto-Japan during the Early Cretaceous (139-135 Ma), age of the sedimentation (Okamoto et al. 2004 and ref. therein), precluding a composition restricted to a pile of oceanic accretionary complexes.

In short, the eclogite unit of central Shikoku shows pressure conditions and a likely fast exhumation rate which are known so far only in relation with a continental subduction, unknown in a setting of oceanic subduction. 
The data coming from petrological and geochemical studies have been already used in order to show that they are supporting the prior underthrusting of a buoyant micro-continent in the case of the post-tectonic Middle Miocene plutonism of Shimanto (Stein et al., 1994, 1996). For instance, Stein et al. (1994) stated that "a simple subduction model does not explain the various magmatic affinities" and that "the proposed collision model could explain (1) the heating source, (2) the various magmatic affinities and also (3) the 0.7-0.8 GPa pressure invoking crustal thickening induced by the collisional event." In the view of those authors, a mantle upwelling, after collision and prior to Shikoku basin subduction, was likely responsible for the necessary heating source. This view was questioned by Shinjoe (1997), who argued that "mantle upwelling as a heat source cannot explain the strict along arc contemporaneity of the felsic magmatism and shift of the magmatism to the Setouchi region". Actually, a slab detachment occurring after the collision can easily explain the asthenospheric upwelling parallel to the belt and the along arc contemporaneity of such a near-trench magmatism. The younger Setouchi arc volcanism, more to the north, was located at the volcanic front linked with the subsequent Shikoku basin subduction. Another critical comment made by Shinjoe (1997) is the lack of direct evidence for the presence and collision of a micro-continent. However, indirect evidence is provided by the existence of high grade enclaves (Stein et al., 1994).

The presence of high grade enclaves, including granulite and not in equilibrium with the Ryoke metamorphism, has also been known for a long time in the Tertiary volcanoes cross-cutting both Ryoke and Tanba zones (e.g. Nureki and Murakami, 1979; Asami and Asami, 1982). But, as pointed out by Faure et al. (1986), if they bring evidence for a sialic basement comprising a deep continental crust, and if the big amount of felsic magmatism produced during the Late Cretaceous and Paleogene suggests the existence of such a sialic basement beneath Tanba and Ryoke (HT metamorphic equivalent of Tanba) zones, its presence could due to two different reasons. Either it is a pre-orogenic basement of TanbaRyoke or a continental block underthrust during the orogeny. Owing to the now generally accepted interpretation of Tanba as an accretionary complex initially formed in a setting of oceanic subduction (see above), the former hypothesis can be discarded. Therefore, such high grade metamorphic rocks must represent the elements of a colliding block arrived at the trench and having underthrust the upper plate. 
Recent geochemical studies dealing with $\mathrm{Sr}-\mathrm{Nd}$ isotopic data of granitic rocks generated in Japan from Paleozoic to Recent (Jahn, 2010 and this volume) bring a new and very strong support for the collisional model. The majority of the granitoids from SW Japan have high initial $87 \mathrm{Sr} / 86 \mathrm{Sr}$ ratios, negative $\varepsilon \mathrm{Nd}(\mathrm{T})$ values and Proterozoic $\mathrm{Sm}-\mathrm{Nd}$ model ages (Jahn, 2010). In other words the melting process producing the magmas involved old (Proterozoic) continental crust. This is true for the Miocene Kashiwajima pluton of the Shimanto belt, which confirms the aforementioned conclusion. But this is also true for the Mesozoic granitoids, namely the Upper Cretaceous and Triassic ones, which post-date the early Cretaceous and the Permian-Triassic tectonic crises respectively. Conversely, the granitoids with a lower Sr ratio, implying a higher proportion of mantle-derived material, were emplaced during the subduction stages of our model, between two collisions. In summary, the granitoids emplaced just after a tectonic crisis show geochemical characteristics of post-collisional ones, quite comparable with those observed in SE China and Taiwan, or in classical collisional orogens in the European Hercynides and Caledonides (Jahn, 2010). This fact argues in favour of the presence of a continental crust beneath the stack of nappes made of accretionary complexes at the moment of the granitoid genesis and emplacement. What is the possible origin of such a continental crust? It was not initially there as the accretionary complexes were likely the result of an oceanic subduction, well documented by the ocean plate stratigraphy and the synchronous arc volcanism. The only possibility is the underthrusting of a continental block, responsible for the tectonic crisis and the nappe emplacement.

\subsection{Summary}

All the lines of evidence: tectonic, geodynamic, petrologic, and geochemical ones invalidate the hypothesis of an intermittent ridge subduction and support the model of the underthrusting of a buoyant block (micro-continent or mature arc) for explaining the episodic tectonic crises. Instead of the accretionary orogeny model most popular during the last decade, the collisional model proposed during the 1980s is the only one accounting for the different data.

\section{Role of tectonic erosion}


A problem underlined by several authors is the scarcity of remnants of old crust in Japan, despite the abundance of continental detrital clasts in the sedimentary rocks, the abundance at once of outcropping Paleozoic granites not visible anymore, etc. One may add now the obvious necessity of the colliding blocks. Isozaki et al. (2010) pointed out that "the recent provenance analysis of detrital zircons has first imaged "ghost" geologic units which once formed in Japan and have already disappeared without evident traces". For such reasons, the role of tectonic erosion has been advocated (Kato and Saka, 2003, 2006; Isozaki et al., 2010).

It is well demonstrated that, during the subduction stage, conspicuous tectonic erosion may occur, instead of accretion, the erosive subduction margins representing $75 \%$ of the present active margins around the world (Scholl and von Huene, 2007, 2010).

This erosion may result from two mechanisms. The first one is the surface erosion of material of the upper plate transported to the trench and then subducted (e.g. von Huene and Cullotta, 1989; von Huene and Lallemand, 1990); it has been working out for the Paleozoic and Cretaceous granites (Isozaki et al., 2010). The second one is the basal erosion. At erosional convergent margins, lower plate underthrusting thins forearc crust by detaching rock from the upper plate and transporting this material to the mantle. A 50 Ma period is long enough to erode the initial width of the volcanic-arc and fore-arc massif of any subduction zone, assuming a mean trench-volcanic-arc landward migration of $5 \mathrm{~km} / \mathrm{Ma}$ and a mean trench-volcanic-arc distance of $250 \mathrm{~km}$ (Lallemand, 1995). Evidence for basal subduction erosion of a forearc is (1) rapid (0.3-0.5 km/Ma) and substantial (3-5 km) subsidence, (2) offshore truncation of cratonic rock, (3) retrograde (landward) migration of the arc-magmatic front, and (4) the coastal and offshore occurrence of arc magmatic rocks (Scholl and von Huene, 2002). During the Cretaceous, the location of volcanic activity moved toward the Asian continent (e.g. Isozaki et al., 2010); the truncation of structures and presence of Cretaceous granite very close to the Japan active trench, at a distance of about a few tens of $\mathrm{km}$ suggest the idea of tectonic erosion which must have destroyed the hangingwall of preMiocene basement of Japan (Yamamoto et al., 2009).

As proposed by Kato and Saka (2006) for the Cretaceous history after collision of the South Kitakami micro-continent, tectonic erosion likely occurred after each collisional event during the following subduction stage. This erosion was responsible for the removal of part of the structures and of the previously underthrusting block. The subsidence accompanying the incipient subduction participated also in hiding the colliding block edge. 


\section{Origin of colliding blocks}

Where are the colliding blocks coming from? Without entering into detail, one can make some remarks. It has been suggested that Proto-Japan was initially attached to Southeast China (Maruyama et al., 1997; Isozaki et al., 2010), as a part of a continental margin affected by rifting during the break-up of the supercontinent Rodinia about 750 to $700 \mathrm{Ma}$ ago. The microcontinent was later separated from SE China and drifted northeastward to form protoJapan. The recent isotopic geochemical data obtained in SW Japan support this evolution model as they share the same characteristics as the South China Block (Jahn, 2010). They add a new line of evidence to some previous ones coming from paleobiogeographic considerations (e.g. Hada et al., 2001; Kido and Sugiyama, 2011).

A rifting episode is known to have occurred in SE China, creating the Nanhua rift, at about 850-800 Ma, later closed by an intracontinental tectonic event around 460-450 Ma (Charvet et al., 2010 and ref. therein). This rifting phase (or a younger one?), closer to the oceanic margin of Catahysia, may have succeeded and opened a new oceanic domain suggested by the around $580 \mathrm{Ma}$ age of the Nomo oceanic crustal remnants. Its closure may have been witnessed by the emplacement of the Ordovician Oeyama ophiolite (Igi et al., 1979, Ishiwatari, 1991; Isozaki, 1996).

It is unclear when the other blocks, responsible for younger collisions, were detached from the main continent. Possibly, they were rifted later, after a collisional phase, during the subsequent subduction stage. For instance, the "Honshu Block" was detached during the opening of the Carboniferous Yakuno oceanic domain and back-collided during the Late Permian (Charvet et al., 1999). Its autochthonous nature, advocated for paleobiogeographic reasons (Charvet et al., 1999), instead of a far-travelled exotic block origin, is supported by the recent geochemical results (Jahn, 2010). The timing of rifting of the other blocks is quite obscure, although likely Paleozoic to Mesozoic. That remains to be documented.

Another still unclear point is the correlation of Hida with the units known in China, Korea, and Russia. It has been naturally considered as a piece of North China or Sino-Korea block because, if one looks at the pre-Sea of Japan configuration, it comes near North Korea (e.g. Kojima, 1989, 2000; Yamakita and Otoh, 1999). But that implies an eastward extension 
of the Triassic Dabie-Sulu-Imjingang collisional suture zone in Japan on the eastern border of Hida, within the Renge belt (e.g. Oh, 2006; Isozaki et al., 2010) and in the Higo belt of Kyushu (Osanai et al., 2006). And, if the Yeongnam massif of SE Korea is assigned initially to the North China Block, it is then interpreted as a major klippe thrust over the UHP belt (Isozaki et al., 2010). This last interpretation is difficult as there is no convincing structural evidence; in Korea, the boundary between the Yeongnam massif of the southeastern Ryeongnam block and the Ogcheon belt is the sub-vertical Triassic Honam strike-slip fault (e.g. Cluzel, 1991; Oh, 2006). And the Yeongnam massif, located to the south of the Ogcheon belt generally correlated with the Huanan rift of South China (e.g. Chang, 1996; Oh, 2006), is likely the extension of the Cathaysian part of South China (Chang, 1996); only the northeastern Taebaeksan part of the Ogcheon belt s. $l$. shows affinities with North China (Chang, 1996). In addition, the correlation between the Hida marginal Renge belt and the $\mathrm{N}$ China-S China suture belt is not sure, as the HP metamorphic ages are quite different, Carboniferous versus Triassic (e.g. Tsujimori et al., 2001; Oh, 2006; Isozaki et al., 2010 and ref. therein). An alternative correlation with the Asian mainland is a link with South China (e.g. Faure and Charvet, 1987; Chough et al., 2000).

A completely different category of interpretations is to consider that the Hida-Oki Block was part of a separate Proto-Japan micro-continent colliding with the Asian mainland in the late Paleozoic (Maruyama et al., 1989) or during the Jurassic (De Jong et al., 2009). The latter hypothesis fits with well established data. For instance, De Jong et al. (2009) include the Khanka Block in their Proto-Japan; it means that the Jiamusi and Bureya blocks, which are similar (Zhou et al., 2010a; Wilde et al., 2010) could be also part of this entity. And, as a matter of fact, the rather well established longitudinal correlation of the MinoTanba and Maizuru-Yakuno zones to the north in NE China and Russia shows all these zones bordering the eastern part of Hida-Khanka-Jiamusi-Bureya massifs (Kojima, 1989; Faure and Natal'in, 1992; Kojima et al., 2000). The docking of this Proto-Japan with Eastern Asia would have happened in the Late Triassic-Early Jurassic (De Jong et al., 2009), which is the time of the collision evidenced by the Heilongjiang HP complex running to the west of the Jiamusi massif (Wu et al., 2007; Zhou et al., 2009). On one hand, this is not incompatible with a common regional origin of those blocks as Jiamusi was maybe part of N Australia at around $500 \mathrm{Ma}$, together with N China, S China, Tarim (Wilde et al., 2000, 2003). In that configuration, what is the eastern extension of the Dabie-Sulu-Imjingang suture? It could the Heilongjiang suture, with some diachroneity. Its connection with the so-called Solonker suture (De Jong et al., 2009), between North China and Mongolia, is unlikely, as those two 
blocks were welded for sure before the Late Permian. On the other hand, the affinity between Hida and Khanka blocks is questioned (Wilde et al., 2010) and the Khanka-Jiamusi was not part of North China nor South China blocks according to Zhou et al. (2010b).

So, the problem of the nature of Hida block is still open. To solve it is beyond the scope of this paper and needs more work. That does not affect the interpretations presented in the next section, in which the Hida area is shown as the hinterland, no matter it was attached or not to the Asian mainland before the Jurassic.

\section{Geodynamic model}

Taking into account the afore-mentioned remarks, a geodynamic model can be proposed for the Late Paleozoic-Triassic and Cretaceous to Paleogene orogenies. It is inspired from the collisional models previously proposed (e.g. Charvet et al., 1985, 1999; Faure et al., 1986; Faure and Charvet, 1987) with the modifications needed due to the recent discoveries mentioned before.

For the Permian-Triassic Akiyoshi orogeny (Fig. 7), the scenario is the following. During the Early Permian, an oceanic domain is subducting beneath another one: the Yakuno one with an anomaslously thick crust (Ishiwatari, 1985, 1991) and likely bordered by an intraoceanic arc (Suda, 2004). The Oga-Akiyoshi seamounts are located in this oceanic domain. The western end is occupied by a Hida domain including the former $340 \mathrm{Ma}$ high-P/T Renge belt (e.g. Isozaki et al., 2010). This subduction leads to the approach of the Honshu microcontinent. During the Late Permian-Early Triassic, the collision of the Honshu block induces the emplacement of the nappes of: HP Suo schists, younger unit of the Sangun belt (e.g. Nishimura, 1998), Yakuno ophiolite, and non metamorphosed Oga-Akiyoshi reefal limestone. It leads also to the deformation of the Carboniferous Unazuki sediments, and the partial resedimentation of ophiolitic olistoliths in the Maizuru Group. It is followed by HT metamorphism and granite emplacement in the Hida domain. This belt, with HP schists, is known to extend towards the south until at least Ishigaki island (Faure and Charvet, 1987; Nishimura, 1998; Nuong et al., 2008).

Regarding the Late Jurassic to Paleocene story, three stages are described (Fig. 8). At around $150 \mathrm{Ma}$, an oceanic realm is subducting beneath Chugoku domain, composed of the previous nappe system unconformably covered by Triassic or Jurassic molasse. Due to that 
consumption, the South Kitakami-Kurosegawa continental block, on which the Torinosu formation is deposited, is approaching the subduction zone, where the Mino-Tanba accretionary prism is built. That may explained the double, from north and south, supply of Precambrian clasts to the Mino sandstone deposition area (Suzuki et al., 1991). The collision of the South Kitakami-Kurosegawa block, likely at around 140 Ma (Otsuki, 1992) rather than at $155 \mathrm{Ma}$ (Kato and Saka, 2003, 2006), reworks the Mino-Tanba accretionary prims as a pile of nappes and the units of the hinterland (Chugoku nappes and Hida s.l.) are thrust again. At around 110-120 Ma, during a new subduction, the Kurosegawa belt is affected by strike-slips faults bounding shallow-water sedimentary basins and the Mino-Tanba stack is affected by the Ryoke HT metamorphism and granitic emplacement. The North Shimanto prism is possibly beginning to grow. The subduction of an oceanic realm rich in Triassic seamounts, reworked as olistoliths in the South Chichibu-Sanbosan sediments, is documented by arc volcanism and responsible for the Sanbagawa HP metamorphism. This ocean is bounded to the east by a continent-type block (Shimanto Block), likely bearing an arc related to the subduction of the fast-moving Izanagi plate (Whittaker et al., 2007a, b). The collision of this block with the active margin takes place between 80 and $60 \mathrm{Ma}$. It induces the exhumation of the Sanbagawa HP schists and eclogites, the re-thrusting of the Kurosegawa-Chichibu domain, the basal thrust contact cutting the former strike-slip faults, and the deformation of the Mino-Tanba stack. The Izanagi-Pacific oceanic ridge arrives at the trench later, at around 60-55 Ma, almost parallel to the margin and not oblique as previously advocated (Whittaker et al., 2007a, b; Smith, 2007; Müller et al., 2008; Yin, 2010).

\section{Conclusions}

The review of the evolution of ideas on the tectonic evolution of Japan during the two last decades leads to the following statements.

1) The structure of SW Japan is made of a pile of sub-horizontal nappes, polydeformed, with a geometry similar to the one encountered in collisional orogens.

2) The mechanisms advocated for the tectonic building within the accretionary orogeny concept (Miyashiro-type orogeny, Nipponides etc.) are inappropriate. Mainly, a steady oceanic subduction with the intermittent "collision" (actually subduction) of an active ridge or seamount chain is unable to build such structures; it induces in fact an acceleration of the tectonic erosion. 
3) Several lines of evidence suggest the episodic thrusting of a buoyant block: microcontinent and/or mature arc. They include: tectonic, geodynamic, petrologic, and geochemical data.

4) The three orogenic crises which took place at around 240, 130, and 80-60 Ma ago in SW Japan can be best explained by a collisional model involving the successive arrival at the former subduction zone of the Honshu Block, the South Kitakami-Kurosegawa Block, and a Shimanto Block. Those features were likely previously separated from South China with which they show affinities.

5) Tectonic erosion plaid likely a major role in removing material during the intervening subduction stages.

6) In the hinterland, the paleogeographic position and the affinity of the Hida block with surrounding units is still unclear. More work is needed to solve this question.

7) Similar tectonic features are due to similar geodynamic causes all around the world. The tectonic architecture of the Japanese islands, resembling the one of some classical collisional orogens, is not an exception and cannot be explained by a process that would be restricted to Japan, as a peculiar and original model of accretionary orogeny.

\section{Acknowledgements}

I greatly thank Professor Ren Jishun for having invited me to publish such a review article in this special volume.

\section{References}

Agard, P., Yamato, P., Jolivet, L., Burov, E., (2009). Exhumation of oceanic blueschists and eclogites in subduction zones: Timing and mechanisms, Earth Science Reviews 92, 53-79. doi: 10.1016/j.earscirev.2008.11.002.

Aitchison, J.C., Hada, S., Yoshikura, S., 1991. Kurosegawa terrane: disrupted remnants of low latitude Paleozoic terrane accreted to SW Japan. Journal of Southeast Asian Earth Sciences 6, 83-92.

Aitchison, J.C., Hada, S., Ireland, T.R., Yoshikura, S., 1996. Ages of Silurian radiolarians from the Kurosegawa terrane, SW Japan constrained by U/Pb SHRIMP data. Journal of Southeast Asian Earth Sciences 14, 53-70. 
Aoki, K., Iizuka, T., Hirata, T., Maruyama, S., Terabayashi, M., 2007. Tectonic boundary between the Sanbagawa belt and the Shimanto belt in central Shikoku, Japan. Journal of the Geological Society of Japan 113(5), 171-183.

Aoki, K., Itaya, T., Shibuya, T., Masago, H., Kon, Y., Terabayashi, M., Kaneko, Y., Kawai, T., Maruyama, S., 2008. The youngest blueschist belt in SW Japan: implication for the exhumation of the Cretaceous Sanbagawa high-P/T metamorphic belt. Journal of Metamorphic Geology 26, 583-602.

Aoya, M., 2001. P-T-D path of eclogite from the Sambagawa belt deduced from combination of petrological and microstructural analyses. Journal of Petrology 42(7), 1225-1248.

Asami, M., Asami, S., 1982. Granulite xenoliths in andesites from Amagiriyama, Kagawa Prefecture. Memoir of the Geological Society of Japan 21, 151-161.

Ballance, P. F., Scholl, D. W., Vallier, T. L., Stevenson, A. J., Ryan, H., Herzer, R. H., 1989. Subduction of a Late Cretaceous seamount of the Louisville chain at the Tonga Trench: a model of normal and accelerated tectonic erosion. Tectonics 8, 953-962.

Barke, R., Lamb, S. 2006. Late Cenozoic uplift of the Eastern Cordillera, Bolivian Andes. Earth and Planetary Science Letters 249, 350-367.

Behrmann, J.H., Lewis, S.D., and Cande, S.C., 1994. Tectonics and geology of spreading ridge subduction at the Chile triple junction-A synthesis of results from Leg 141 of the Ocean Drilling Program: Geologische Rundschau 83(4), 832-852, doi: 10.1007/BF00251080.

Bourgois, J. H., Martin, Lagabrielle, Y., Le Moigne, J., and Frutos, J., 1996. Subduction erosion related to spreading-ridge subduction: Taitao peninsula (Chile margin triple junction area). Geology 24, 723-726.

Cadet, J.P., Kobayashi, K., Aubouin, J., Boulègue, J., Deplus, C., Dubois, J., von Huene, R., Jolivet, L., Kanazawa, T., Kasahara, J., Koizumi, K., Lallemand, S., Nakamura, Y., Pautot, G., Suyehiro, K., Tani, S., Tokuyama, H., Yamazaki, T., 1987. The Japan Trench and its juncture with the Kuril Trench: Cruise results of the Kaiko project, Leg 3, Earth and Planetary Science Letters 83, 267-284.

Cawood, P. A., Kröner, A., Collins, W. J., Kusky, T. M., Mooney W. D., Windley, B. F., 2009. Accretionary orogens through Earth history. In: Cawood, P. A., Kröner, A. (Eds.), Earth Accretionary Systems in Space and Time: Geological Society, London, Special Publications 318, 1-36. doi:10.1144/SP318.1. 
Caridroit, M., Ichikawa, K., Charvet, J., 1985. The Ultra-Tamba zone, a new unit in the inner zone of SW Japan. Its importance in the nappe structure after the example of the Maizuru area. Earth Sciences (Chikyu Kagaku) 39(3), 210-219.

Caridroit, M., Faure, M., Charvet, J., 1987. Nouvelles données stratigraphiques et structurales sur le Paléozoïque supérieur des zones internes du Japon sud-ouest. Un essai sur l’orogenèse permienne. Bulletin de la Société géologique de France 8, III(4), 683-691.

Chang, E. Z., 1996. Collisional orogene between north and south China and its eastern extension in the Korea Peninsula. Journal of Southeast Asian Earth Sciences 13(3-5), 267-277.

Charvet, J., 1980. Subduction et tectonique : quelques réflexions sur "l'orogénèse de type pacifique” à propos du Japon sud-ouest. Comptes Rendus Sommaires de la Société géologique de France, 2, 58-61.

Charvet, J., Cadet, J.P., Faure, M., Aubouin, J., 1983. Sur l'importance de la tectonique de nappe mésozoïque au Japon central et méridional. Comptes Rendus de l'Académie des Sciences Paris 296, 1278-1286.

Charvet, J., Cluzel, D., Faure, M., Caridroit, M., Shu, L.S., Lu, H.F., 1999. Some tectonic aspects of the pre-Jurassic accretionary evolution of East Asia. In: Metcalfe, I, Ren, J.S., Charvet, J., Hada, S. (Eds.), Gondwana dispersion and Asian accretion, IGCP 321 Final Results Volume, Balkema, 37-65.

Charvet, J., Faure, M., 1984. Mesozoic orogeny, microblocks and longitudinal left-lateral motions in SW Japan. Annales de la Société Géologique du Nord CIII, 361-375.

Charvet, J., Faure, M., Caridroit, M., Guidi, A., 1985. Some tectonic and tectogenetic aspects of SW Japan: an alpine-type orogen in an island-arc position. In: Nasu, N. et al. (Eds.), Formation of the Active Ocean Margins, Terrapub, Tokyo, 791-817.

Charvet, J., Shu, L.S., Faure, M., Choulet, F., Wang, B., Lu, H.F., Le Breton, N., 2010.

Structural development of the Lower Paleozoic belt of South China: Genesis of an intracontinental orogen. Journal of Asian Earth Sciences 39, 309-330.

Chough, S.K., Kwon, S.T., Ree, J.H., Choi, D.K., 2000. Tectonic and sedimentary evolution of the Korean peninsula: a review and new view. Earth-Science Reviews 52, 175-235. Clift, P. D., Pecher, I., Kukowski, N., Hampel, A., 2003. Tectonic erosion of the Peruvian forearc, Lima Basin, by subduction and Nazca Ridge collision. Tectonics 22(3), 1023. Doi: 10.1029/2002TC001386. 
Cluzel, D., 1991. Late Palaeozoic to Early Mesozoic geodynamic evolution of the circumPacific orogenic belt in South Korea and in southwestern Japan. Earth and Planetary Science Letters 108, 289-305.

DeCelles, P. G., Horton, B. K., 2003. Early to middle Tertiary foreland basin development and the history of Andean crustal shortening in Bolivia. Geological Society of America Bulletin 115(1), 58-77.

De Jong, K., Kurimoto, C., Ruffet, G., 2009. Triassic 40Ar/39Ar ages from the Sakaigawa unit, Kii Peninsula, Japan: implications for possible merger of the Central Asian Orogenic Belt with large-scale tectonic systems of the East Asian margin. International Journal of Earth Sciences 98, 1529-1556.

Eberhart-Phillips, D., Christensen, D. H., Brocher, T. M., Hansen, R., Ruppert, N. A., Haeussler, P. J., Abers, G. A. , 2006. Imaging the Transition from Aleutian subduction to Yakutat collision in central Alaska with local earthquakes and active source data. Journal of Geophysical Research 111, B11303, doi:10.1029/2005JB004240.

Ehiro, M. (2000). Relationships in tectonic framework among the South Kitakami and Hayachine Tectonic Belts, Kurosegawa Belt, and "Paleo-Ryoke Belt". Geological Society of Japan Memoir 56, 53-64.

Enami, M., Miyamoto, A., 2001. Revised thermobarometry of kyanite-eclogite in the Sanbagawa metamorphic belt of the Bessi area, Japan. Abstracts for Annual Meeting of the Japanese Association of Mineralogy Petrology Economic Geology, 207.

Enami, M., Mizukami, T., Yokoyama, K., 2004. Metamorphic evolution of garnet-bearing ultramafic rocks from the Gongen area, Sanbagawa belt, Japan. Journal of Metamorphic Geology 22, 1-15.

Endo, S., 2010. Pressure-temperature history of titanite-bearing eclogite from the Western Iratsu body, Sanbagawa Metamorphic Belt, Japan. Island Arc 19, 313-335.

Espurt, N., Baby, P., Brusset, S., Roddaz, M., Hermoza, W., Regard, V., Antoine, P.O., Salas-Gismondi, R., and Bolanos, R., 2007, How does the Nazca Ridge subduction influence the modern Amazonian foreland basin? Geology 35(6), 515-518, doi: 10.1130/G23237A.1.

Faure, M., 1983. Eastward ductile shear during the early tectonic phase in the Sanbagawa belt. Journal of the Geological Society of Japan 89, 319-329.

Faure, M., Caridroit, M. 1983. Tectoniques tangentielles superposées dans les zones “internes” du Japon SW, d'après l'exemple de la région de Kamigori. Comptes Rendus de l'Académie des Sciences, Paris, II 197, 165-170. 
Faure, M., Caridroit, M., Charvet, M. 1986. Tectonic evolution of the Late Jurassic orogeny of SW Japan. New structural data and synthesis. Tectonics 5, 1089-1113.

Faure, M., Caridroit, M., Guidi, A., Charvet, J., 1987. The late Jurassic orogen of southwest Japan: nappe tectonics and longitudinal displacement. Bulletin de la Société géologique de France 8, III(3), 477-485.

Faure, M., Charvet, J., 1983. Tangential tectonics in the Chichibu zone from the example of Eastern Shikoku. Proceedings of the Japan Academy 59, B(5), 117-120.

Faure, M., Charvet, J., 1984. Mesozoic nappe structures in SW Japan, from the example of Eastern Shikoku and Kinki area. Sciences Géologiques, Strasbourg 37(1), 51-63.

Faure, M., Charvet, J. 1987. Late Permian/early Triassic orogeny in Japan: piling up of nappes, tranverse lineation and continental subduction of the Honshu block. Earth and Planetary Science Letters 84, 295-308.

Fisher, D.M., Gardner, T.W., Sak, P., Sanchez, J.D., Murphy, K., Vannucchi, P., 2004. Active thrusting in the inner forearc of an erosive convergent margin, Pacific coast, Costa Rica. Tectonics 23, doi:10.1029/2002TC001464, 13 p.

Fryer, P., Hussong, D.M., 1985. Seamarc II studies of subducting seamounts. In: Nasu, N. et al. (Eds.), Formation of Active Ocean Margins, Terrapub, Tokyo, 291-306.

Fryer, P., Smoot, N.C., 1985. Processes of seamount subduction in the Mariana and Izu-Bonin Trenches. Marine Geology 64, 77-90.

Fuis, G.S., Moore, T.E., Plafker, G., Brocher, T.M., Fisher, M.A., Mooney, W.D., Nokleberg, W.J., Page, R.A., Beaudoin, B.C., Christensen, N.I., Levander, A.R., Lutter, W.J., Saltus, R.W., Ruppert, N.A., 2008. Trans-Alaska Crustal Transect and continental evolution involving subduction underplating and synchronous foreland thrusting. Geology 36(3), 267-270, doi: 10.1130/G24257A.1.

Fujimoto, H., 1937. The nappe theory with reference to the northeastern part of the KantoMountainland. Science Report Tokyo Bunrika Daigaban C(1), 215-242.

Gardner, T.W., Marshall, J., Merritts, D., Bee, B., Burgette, R., Burton, E., Cooke, J., Kehrwald, N., Protti, M., Fisher, D., Sak, P., 2001. Holocene forearc deformation in r esponse to seamount subduction, Peninsula de Nicoya, Costa Rica. Geology 29, 151154, doi: 10.1130/0091-7613(2001)029<0151:HFBRIR>2.0.CO;2.

Gotberg, N., McQuarrie, N., Caillaux, V. C., 2010. Comparison of crustal thickening budget and shortening estimates in southern Peru $\left(12-14^{\circ} \mathrm{S}\right)$ : Implications for mass balance and rotations in the "Bolivian orocline". Geological Society of America Bulletin 122(5/6); 727-742; doi: 10.1130/B26477.1 
Guidi, A., Charvet, J., Sato, T., Takizawa, S., 1983. Les structures tangentielles anté-Crétacé de la chaîne du Japon Sud-Ouest dans les Monts Kanto: résultats préliminaires. Comptes Rendus de l’ Académie des Sciences Paris 298, 307-312.

Hada, S., Ishii, K., Landis, C.A., Aitchison, J., Yoshikura, S., 2001. Kurosegawa Terrane in Soutwest Japan: Disrupted remnants of a Gondwana-derived terrane. Gondwana Research, 4(1), 27-38.

Hada, S., Yoshikura, S., Gabites, J. E., 2000. U-Pb zircon ages for the Mitaki igneous rocks, Siluro-Devonian tuff, and granitic boulders in the Kurosegawa Terrane, Southwest Japan. Memoirs of the Geological Society of Japan 56, 183-198.

Hartley, A.J., May, G., Chong, G., Turner, P., Kape, S. J., Jolley, E. J., 2000. Development of a continental forearc: A Cenozoic example from the Central Andes, northern Chile. Geology 28(4), 331-334.

Hattori, K., Wallis, S., Enami, M., Mizukami, T., 2010. Subduction of mantle wedge peridotites: Evidence from the Higashi-Akaishi ultramafic body in the Sanbagawa metamorphic belt. The Island Arc 19, 192-207.

Hayasaka, Y., Hara, I., 1982. Discovery of Jurassic radiolarian in the Chugoku belt and its structural significance. $89^{\text {th }}$ Annual Meeting of the Geological Society Japan, 556.

Igi, S., Hattori, H., Shibata, K., 1979. Nomo metagabbro complex and their 450 m.y. ages as a clue to thebasement geology - a proposal of 'Saihi Structural zone' including the preSilurian basements in westernmost part of the Japanese Islands. In Kano, H. (Ed.), The basement of the Japanese Islands, 261-80 (in Japanese with English abstract).

Ishiwatari, A., 1985. Granulite-facies metacumulates of the Yakuno ophiolite, Japan: evidence for unusually thick oceanic crust. Journal of Petrology 26, 1-30.

Ishiwatari, A., 1991. Ophiolites in the Japanese islands: Typical segment of the circumPacific multiple ophiolite belts. Episodes 14(3), 274-279.

Isozaki, Y., 1996. Anatomy and genesis of a subduction-related orogen: A new view of geotectonic subdivision and evolution of the Japanese Islands. The Island Arc 5, 289320 .

Isozaki, Y., 1997. Jurassic accretion tectonics of Japan. The Island Arc 6, 25-51.

Isozaki, Y., Aoki, K., Nakama, T., Yanai, S., 2010. New insight into a subduction-related orogen: A reappraisal of the geotectonic framework and evolution of the Japanese Islands. Gondwana Research 18, 82-105.

Isozaki, Y., Itaya, T., 1991. Pre-Jurassic klippe in northern Chichibu Belt in west-central Shikoku, Southwest Japan-Kurosegawa Terrane as a tectonic outlier of the pre- 
Jurassic rocks of the Inner Zone. Journal of the Geological Society of Japan 97, 431450 (in Japanese with English abstract).

Isozaki, Y., Maruyama, S., Furuoka, F., 1990. Accreted oceanic materials in Japan.

Tectonophysics 181, 179-205.

Ito, T., Kojima, Y., Kodaira, S., Sato, H., Kaneda, Y., Iwasaki, T., Kurashimo, E., Tsumura, N., Fujiwara, A., Miyauchi, T., Hirata, N., Harder, S., Miller, K., Murata, A., Yamakita, S., Onishi, M., Abe, S., Sato, T., Ikawa, T., 2009. Crustal structure of southwest Japan, revealed by the integrated seismic experiment Southwest Japan 2002. Tectonophysics 472, 124-134.

Jahn, B.M., 2010. Accretionary orogen and evolution of the Japanese islands - Implications from a Sr-Nd isotopic study of the Phanerozoic granitoids from SW Japan. American Journal of Science 310, 1210-1249, DOI 10.2475/10.2010.02.

Jolivet, L., 1986. The Hokkaido Central belt, the succession of tectonic stages. Bulletin de la Société géologique de France 2, 311-327.

Jolivet, L., Cadet, J.P., Lalevée, F., 1987. Tectonic evolution of northeast Asia and the collision of the Okhostsk microcontinent. Tectonophysics 160, 23-47.

Kawamura, T., Onishi, M., Kurashimo, E., Ikawa, T., Tanio I., 2003. Deep seismic reflection experiment using a dense receiver and sparse shot technique for imaging the deep structure of the Median Tectonic Line (MTL) in east Shikoku, Japan. Earth Planets Space 55, 549-557.

Kido, E., Sugiyama, T. 2011. Silurian rugose corals from the Kurosegawa Terrane, Southwest Japan, and their paleobiogeographic implications. Bulletin of Geosciences 86(1), 4961. Czech Geological Survey, Prague.

Kimura, G., 1997. Cretaceous episodic growth of the Japanese Islands. The Island Arc 6, 5268.

Kawato, K., Isozaki, Y., Iitaya, T., 1991. Geotectonic boundary between the Sanbagawa and Chichibu belts in central Shikoku, Southwest Japan. Journal of the Geological Society of Japan 97(12), 959-975.H

Kobayashi, K., Cadet, J.P., Aubouin, J., Boulègue, J., Dubois, J., von Huene, R., Jolivet, L., Kanazawa, T., Kasahara, J., Koizumi, K., Lallemand, S., Nakamura, Y., Pautot, G., Suyehiro, K., Tani, S., Tokuyama, H., Yamazaki, T., 1987. Normal faulting of the Daiichi-Kashima seamount in the Japan Trench revealed by the Kaiko 1 Cruise, Leg 3. Earth and Planetary Science Letters 83, 257-266. 
Kojima, S., 1989. Mesozoic terrane accretion in northeast China, Shikote-Alin and Japan regions. Palaeogeography, Palaeoclimatology, Palaeoecology 69, 213-232.

Kojima, S., Kemkin, I. V., Kametaka, M., Ando, A., 2000. A correlation of accretionary complexes of southern Shikote-Alin of Russia and the Inner Zone of Southwest Japan. Geosciences Journal 4(3), 175-185.

Komatsu, M., Miyashita, S., Maeda, J., Osanai, Y., Toyoshima, T., 1983. Disclosing of a deepest section of continental type crust upthrust as the final event of collision of arcs in Hokkaido. In: Hashimoto M., Uyeda S. (Eds.), Accretion Tectonics in the Circum Pacific regions. Terrapub, Tokyo, 149-65.

Lallemand, S., 1995. High rates of arc consumption by subduction processes: Some consequences. Geology 23, 551-554.

Lallemand, S., Chamot-Rooke, N., 1986. Sur la cause du décrochement senestre entre les fosses du Japon et des Kouriles: Subduction-collision d'un ancien volcan sous-marin. Comptes Rendus des Séances de l'Académie des Sciences, Ser. H 303(16), 14431448.

Lallemand, S., Le Pichon, X., 1987. Coulomb wedge model applied to the subduction of seamounts in the Japan Trench. Geology 15, 1065-1069.

Lyon-Caen, H., Molnar, P., Suarez, G., 1985. Gravity anomalies and flexure of the Brazilian Shield beneath the Bolivian Andes. Earth and Planetary Science Letters 75, 8192.H616ne Lyon-Caen en *, Peter Molnar and

Maruyama, S., 1997. Pacific-type orogeny revisited: Miyashiro-type orogeny proposed. The Island Arc 6, 91-120.

Maruyama, S., Banno, S., Matsuda; T., Nakajima, T., 1984. Kurosegawa zone and its bearing on the development of the Japanese Islands. Tectonophysics 110(1-2), 47-60.

Maruyama, S., Isozaki, Y., Kimura, G., Terabayashi, M., 1997. Paleogeographic Maps of the Japanese Islands: plate tectonic synthesis from $750 \mathrm{Ma}$ to the present. The Island Arc 6, 121-142.

Maruyama, S., Liou, J.G., Terabayashi, M, 1996. Blueschists and eclogites of the world and their exhumation. International Geology Review 38, 490-594.

Maruyama, S., Liou, J. G., Seno, T. 1989. Mesozoic and Cenozoic evolution of Asia. In: Ben Avraham, Z. (Ed.), The Evolution of the Pacific Ocean Margins. Oxford Monographs in Geology and Geophysics 8, 75-99.

Masago, H., Okamoto, K., Terabayashi, M. 2005. Exhumation tectonics of the Sanbagawa High-Pressure metamorphic belt, Southwest Japan-Constraints from the upper and lower boundary faults. International Geology Review 47, 1194-1206. 
Matsuda, T., Isozaki, 1991. Well-documented travel history of Mesozoic pelagic cherts in Japan: from remote ocean to subduction zone. Tectonics 10, 475-499.

Matsuda, T., Uyeda, S., 1971. On the Pacific-type orogeny and its model: extension of the paired metamorphic belts concept and possible origin of marginal seas. Tectonophysics 11, 5-27.

Matsuoka, A., 1992. Jurassic-Early Cretaceous tectonic evolution of the Southern Chichibu terrane, south-west Japan. Paleogeography, Paleoclimatology, Paleoecology 96, 7188.

McQuarrie, N., 2002. The kinematic history of the central Andean fold-thrust belt, Bolivia: Implications for building a high plateau. Geological Society of America Bulletin 114(8), 950-963.

McQuarrie, N., DeCelles, 2001; Geometry and structural evolution of the central Andean backthrust belt, Bolivia. Tectonics 20(5), 669-692.

Mizukami, T., Wallis, S. R., 2005. Structural and petrological constraints on the tectonic evolution of the garnet-lherzolite facies Higashi-Akaishi peridotite body, Sanbagawa belt, SW Japan. Tectonics 24, doi:10.1029/2004TC001733.

Mori, H., Wallis, S., 2010. Large-scale folding in the Asemi-gawa region of the Sanbagawa Belt, southwest Japan. The Island Arc 19, 357-370.

Müller, J. P., Kley, J., Jakobshagen, V., 2002. Structure and Cenozoic kinematics of the Eastern Cordillera, southern Bolivia (21_S). Tectonics 21(5), 1037, doi:10.1029/2001TC001340, 2002

Müller, R.D., Sdrolias, M., Gaina, C., Steinberger, B., Heine, C., 2008. Long-Term Sea-Level Fluctuations Driven by Ocean Basin Dynamics. Science 319, 1357. DOI: $0.1126 /$ science. 1151540

Nishimura, Y., 1998. Geotectonic subdivision and areal extent of the Sangun belt, Inner Zone of Southwest Japan. Journal of Metamorphic Geology 16, 129-140. doi:

10.1111/j.1525-1314.1998.00059.x

Nuong, N. D., T. Itaya, T., Nishimura, Y., 2008. Age (K-Ar phengite)-temperature-structure relations: a case study from the Ishigaki high-pressure schist belt, southern Ryukyu Arc, Japan. Geological Magazine 145, 677-684.

Nureki, T., Murakami, N., 1979. A general survey of xenoliths found in the Cenozoic volcanic rocks in West Japan. In: Kano, H. (Ed.), The basement of the Japanese islands, Akita University, Akita, Japan, 217-232. 
Oh, C.W., 2006. A new concept on tectonic correlation between Korea, China and Japan: Histories from the late Proterozoic to Cretaceous. Gondwana Research 9, 47-61.

Okamoto, K., Shinjoe, H., Katayama, I., Terada, K., Sano, Y., Johnson, S., 2004. SHRIMP $\mathrm{U}-\mathrm{Pb}$ zircon dating of quartz-bearing eclogite from the Sanbagawa Belt, south-west Japan: implications for metamorphic evolution of subducted protolith. Terra Nova 16, 81-89. doi: 10.1111/j.1365-3121.2004.00531.x

Osanai, Y., Owada, M., Kamei, A., Hamamoto, T., Kagami, H., Toyoshima, T., Nakano, N., Nam, T.N., 2006. The Higo metamorphic complex in Kyushu, Japan as the fragment of Permo-Triassic metamorphic complexes in East Asia. Gondwana Research 9(1-2), 152-166.

Osozawa, S., Pavlis, T., 2007. The high P/T Sambagawa extrusional wedge, Japan. Journal of Structural Geology 29, 1131-1147.

Ota,T., Terabayashi, M., Katayama, I., 2004. Thermobaric structure and metamorphic evolution of the Iratsu eclogite body in the Sanbagawa belt, central Shikoku, Japan. Lithos 73, 95-126.

Otsuki, K., 1992. Oblique subduction, collision of microcontinents and subduction of oceanic ridge: Their implications on the Cretaceous tectonics of Japan. The Island Arc 1, 5163.

Sasaki, H., Isozaki, Y., 1992. Low-angle thrust between the Sanbagawa and Shimanto belts in central Kii peninsula, SW Japan. Journal of the Geological Society of Japan 98, 57-60.

Schmitz, M. 1994. A balanced model of the southern Central Andes. Tectonics 13(2), 484492.

Scholl, D. W., 2007. Viewing the tectonic evolution of the Kamchatka-Aleutian (KAT) connection with an Alaska crustal extrusion perspective. Geophysical Monograph Series 172, 3-35.

Scholl, D. W., von Huene, R., 2002. Basal Subduction Erosion and the Formation of the Aleutian Terrace and Underlying Forearc Basin. Proceeding of the 3rd International Biennial Workshop on Subduction Processes, University of Alaska, Fairbanks, June $10-14,2002$.

Scholl, D. W., von Huene R. 2007. Crustal recycling at modern subduction zones applied to the past-Issues of growth and preservation of continental basement crust, mantle geochemistry, and supercontinent reconstruction. In: Hatcher, R.D., Jr., Carlson, M.P., McBride, J.H., Martínez Catalán, J.R. (Eds.), 4-D Framework of Continental Crust. Geological Society of America Memoir 200, 9-32, doi: 10.1130/2007.1200(02). 
Scholl, D. W., von Huene R. 2010. Subduction zone recycling processes and the rock record of crustal suture zones. Canadian Journal of Earth Sciences 47, 633-654.

Sengör, A. M. C., Natal'in, B. A., 1996. Turkic-type orogeny and its role in the making of the continental crust. Annual Review of Earth and Planetary Sciences 24, 263-337, doi:10.1146/annurev.earth.24.1.263.

Smith, A.D., 2007. A plate tectonic model for Jurassic to Recent intraplate volcanism in the Pacific Ocean basin, Geological Society of America Special Paper 430, 471-496. doi:10.1130/2007.2430(23).

Stein, G., Charvet, J., Lapierre, H., Fabbri, O., 1994. Geodynamic setting of volcano-plutonic rocks in so-called "paleo-accretionary prisms": Fore-arc activity or post-collisional magmatism? The Shimanto belt as a case study. Lithos 33(1-3), 85-107.

Stein G, Lapierre H., Charvet J., 1996. The Miocene Ashizuri complex (SW Japan); source and magma differentiation of an alkaline plutonic assemblage in an island-arc environment: Bulletin de la Société géologique de France 167(1), 125-139.

Suda, Y., 2004. Crustal anatexis and evolution of granitoid magma in Permian intra-oceanic arc, the Asago body of the Yakuno ophiolite, Southwest Japan. Journal of Mineralogical and Petrological Sciences 99, 339-356.

Suzuki, H., Isozaki, Y., Itaya, T., 1990. Tectonic superposition of the Kurosegawa Terrane upon the Sanbagawa metamorphic belt in eastern Shikoku, Southwest Japan-K-Ar ages of weakly metamorphosed rocks in northeastern Kamikatsu Town, Tokushima Prefecture. Journal of the Geological Society of Japan 96(2), 143-153.

Suzuki, K., Adachi, M., Tsuyoshi Tanaka, T., 1991. Middle Precambrian provenance of Jurassic sandstone in the Mino Terrane, central Japan: Th-U-total Pb evidence from an electron microprobe monazite study. Sedimentary Geology 75(1-2), 141-147.

Takasu, A., 1989. P-T histories of peridotite and amphibolite tectonic blocks in the Sanbagawa metamorphic belt, Japan. Special Publication of the Geological Society $43,533-538$.

Terabayashi, M., Okamoto, K., Yamamoto, H., Kaneko, Y., Ota, T., Maruyama, S., Katayama, I., Komiya, T., Ishikawa, A., Anma, R., Ozawa, H., Windley, B.F., Liou, J.G., 2005. Accretionary complex origin of the mafic-ultramafic bodies of the Sanbagawa belt, central Shikoku, Japan. International Geology Review 47, 1058-1078. Tsujimori, T., Hyoudo, H., Itaya, T., 2001. 40Ar/39Ar phengite age constrains on the exhumation of the eclogite facies rocks in the Renge metamorphic belt, SW Japan. 2001 Japan Earth Planetary Sciences Joint Meeting, Tokyo, Japan, abs. 
Utsunomiya, A., Jahn, B.M., Okamoto, K., Ota, T., Shinjoe, H., 2011. Intra-oceanic island arc origin for Iratsu eclogites of the Sanbagawa belt, central Shikoku, southwest Japan. Chemical Geology 280, 97-114.

Von Huene, R., 2008. When seamounts subduct. Science 321, 1165-1166. doi: 10.1126/science. 1162868 .

von Huene, R., Cullotta, R., 1989. Tectonic erosion at the front of the Japan convergent margin. Tectonophysics 160, 75-90, doi: 10.1016/0040-1951(89)90385-5.

von Huene, R., Lallemand, S., 1990. Tectonic erosion along the Japan and Peru convergent margins. Geological Society of America Bulletin 102, 704-720.

von Huene, R., Ranero, C.R., 2010. Neogene collision and deformation of convergent margins along the backbone of the Americas. Geological Society of America Memoir 204, 67-83, doi: 10.1130/2009.1204(03).

Wakita, K., 2000. Melanges of the Mino Terrane. Memoirs of the Geological Society of Japan 55, 145-163 (in Japanese with English abstract).

Wakita, K., Metcalfe, I., 2005. Ocean Plate Stratigraphy in East and Southeast Asia. Journal of Asian Earth Sciences 24, 679-702.

Wallis,S. R., Aoya, M., 2000. A re-evaluation of eclogite facies metamorphism in SW Japan: Proposal for an eclogite nappe. Journal of Metamorphic Geology 18, 653-64.

Wallis, S., Anczkiewicz, R., Endo, S., Aoya, M., Platt, J.P., Thirlwall, M., Hirata, T., 2009. Plate movements, ductile deformation and geochronology of the Sanbagawa belt, SW Japan: tectonic significance of 88-89 Ma Lu-Hf eclogite ages. Journal of Metamorphic Geology 27, 2, 93-105.

Wilde, S. A., Zhang, X. Z., Wu, F. Y. 2000. Extension of a newly-identified $500 \mathrm{Ma}$ metamorphic terrain in North East China: further U-Pb SHRIMP dating of the Mashan Complex, Heilongjiang Province, China. Tectonophysics 328, 115-130.

Wilde, S. A., Wu, F. Y., Zhang, X. Z. 2003. Late Pan-African magmatism in Northeastern China: SHRIMP U-Pb zircon evidence from granitoids in the Jiamusi Massif. Precambrian Research, 122, 311-327.

Wilde, S. A., Wu, F-Y, Zhao, G.-C., 2010. The Khanka Block, NE China, and its significance for the evolution of the Central Asian Orogenic Belt and continental accretion Geological Society, London, Special Publications 338, 117-137. doi:10.1144/SP338.6. Whittaker, J.M., Mueller, R.D., Leitchenkov, G., Stagg, H., Sdrolias, M., Gaina, C., Goncharov, A., 2007a. Major Australian-Antarctic plate reorganization at HawaiianEmperor bend time. Science 318 (5847), 83-86. 
Whittaker, J., Müller, R.D., Sdrolias, M., 2007b. Revised history of Izanagi-Pacific ridge subduction. Joint NSF-Margins and Ifree Workshop: Subduction factory studies in the Izu-Bonin-Mariana arc system: results and future plans, Honolulu, Hawaii, Abstracts, 86-87, and poster.

Wu, F. Y.,Yang, J. H., Lo, C. H.,Wilde, S. A., Sun, D. Y., Jahn, B.-M., 2007. The Heilongjiang Group: a Jurassic accretionary complex in the Jiamusi Massif at the western Pacific margin of northeastern China. The Island Arc 16, 156-172.

Yamakita, S., Otoh, S., 1999. Reconstruction of the geological continuity between Primorye and Japan before the opening of the Sea of Japan. Institute for Northeast Asian Studies Research Annual 24, 1-16 (in Japanese).

Yamamoto, S., Senshu, H., Rino, S., Omori, S., Maruyama, S., 2009. Granite subduction: Arc subduction, tectonic erosion and sediment subduction. Gondwana Research 15, 443453.

Yin, A., 2010. Cenozoic tectonic evolution of Asia: A preliminary synthesis. Tectonophysics 488, 293-325.

Yoshikura, S., Hada, S., Isozaki, Y., 1990. Kurosegawa Terrane. In: Ichikawa, K., Mizutani, S., Hara, I., Hada, S., Yao, A. (Eds.), Pre-Cretaceous Terranes of Japan. Publications of IGCP No. 224, Osaka, 185-201.

Zhou, J.-B., Wilde, S. A., Zhang, X.-Z., Zhao, G.-C., Zheng, C.-Q., Wang, Y.-J., Zhang, X.H., 2009. The onset of Pacific margin accretion in NE China: Evidence from the Heilongjiang high-pressure metamorphic belt. Tectonophysics 478 (2009) 230-246.

Zhou, J.-B., Wilde, S. A., Zhao, G.-C., Zhang, X.-Z., Zheng, C.-Q., Wang, H., Zeng, W.-S., 2010a. Pan-African metamorphic and magmatic rocks of the Khanka Massif, NE China: further evidence regarding their affinity. Geological Magazine, 1-13.

Cambridge University Press. doi:10.1017/S0016756810000063.

Zhou, J.B., Wilde, S. A., Zhao, G-C, Zhang, X-Z, Wang, H., Zeng, W.-S., 2010b. Was the easternmost segment of the Central Asian Orogenic Belt derived from Gondwana or Siberia: An intriguing dilemma? Journal of Geodynamics 50, 300-317.

\section{Figure captions}


Figure 1. Sketch map showing the main divisions of Japan (after Faure et al., 1987). The Green Schist Nappe corresponds to Sanbagawa zone, the Superficial Nappe to North Chichibu.

Figure 2. Schematic structural map of SW Japan, emphasizing the structures of the Late Jurassic-Early Cretaceous orogen (after Faure et al., 1987). Note the tectonic windows of the Tanba zone beneath the Sangun-Maizuru units partly inherited from the Chugoku nappe system of the Late Permian-Triassic orogeny. Black spots in the Sangun-Maizuru zone represent the Triassic (T) and Jurassic ( $\mathrm{J})$ molasses.

Figure 3. a) Schematic general cross-section of SW Japan (after Charvet et al., 1985). 1: Tertiary and Cretaceous volcanic; 2: Yakuno ophiolitic complex; 3: Sangun schists; 4: Permian Maizuru Group; 5: Tanba zone units; 6: Upper Cretaceous Izumi Group; 7: Cretaceous Sennan Group volcanic; 8: Inferred basement rocks of the Ryoke area; 9: High-grade (top) and low-grade (bottom) of the Sanbagawa basic schists; 10: Cover and basement of the Kurosegawa block; 11-12: Shimanto; 13: Miocene to Recent deposits off Shikoku; 14: "Younger" (top) and "Older" (bottom) granites of Ryoke zone; 15: Miocene granitoids intruding Shimanto. b) Zoom on the cross-section of the “outer zones" in eastern Shikoku island (after Charvet et al., 1985). A: Izumi Group; B: Cretaceous deposits of Central Chichibu; C: Shimanto; D: Sanbagawa high-grade schists; E: Low-grade schists; F: Sandstone unit; G: Assumed Oboke-Kurosegawa basement; H: Pre-Cretaceous sediments of domain III; I: Olistostrome of the Chichibu nappe; J: Green rocks; K: Stratigraphic cover of the Mikabu green rocks; L: Thrust contact of phase 1; M: Thrust contact of phase 2. O: Oboke; Ku: Kurosegawa.

Figure 4. Simplified anatomy of SW Japan emphasizing the superimposition of accretionary complexes younging downward and the absence of basement continent-like units (after Isozaki et al., 2010). AC and meta-AC: Accretionary complexes and metamorphosed accretionary complexes; WB plane: Wadati-Benioff plane; $\mathrm{Ng}$ HmTL: Nagato-Hida marginal Tectonic Line; I-KTL: Ishigaki-Kuga Tectonic Line; BTL: Butsuzo Tectonic Line; ATL: Aki Tectonic Line.

Figure 5. Two different interpretations of the structure of Sanbagawa-Chichibu-Kurosegawa domain. a) Interpretation advocated in this article, cross-section modified after Charvet 
et al. (1985): the Kurosegawa unit is part of a previous block (South KitakamiKurosegawa) underthrust during the Early Cretaceous, affected by strike-slip faulting, and re-thrust during the Late Cretaceous-Paleocene event involving Sanbagawa thrusting above N Shimanto. b) Interpretation assuming that the Kurosegawa old rocks are olistoliths in the Chichibu klippe system (after Masago et al., 2005).

Figure 6. Block-diagram showing the relationships between Shimanto, Sanbagawa, and Chichibu-Kurosegawa in eastern Kii Peninsula (after Kato and Saka, 2006). Note the faults within the Kurosegawa Terrane cut by the BTL, thrust contact with Shimanto.

Figure 7. Schematic geodynamic model, in cross-section, for the Late Permian-Triassic orogeny, advocating a collision between the Hinterland (Hida s. 1.) and a Honshu Block.

Figure 8. Schematic geodynamic model, in cross-section, for the 140-130 and 80-60 Ma orogenies, assigned to the two successive collisions of South Kitakami-Kurosegawa and Shimanto blocks. Note that the Izanagi-Pacific ridge arrives at the active margin after the main tectonic episode involving the exhumation of the Sanbagawa HP schists. 


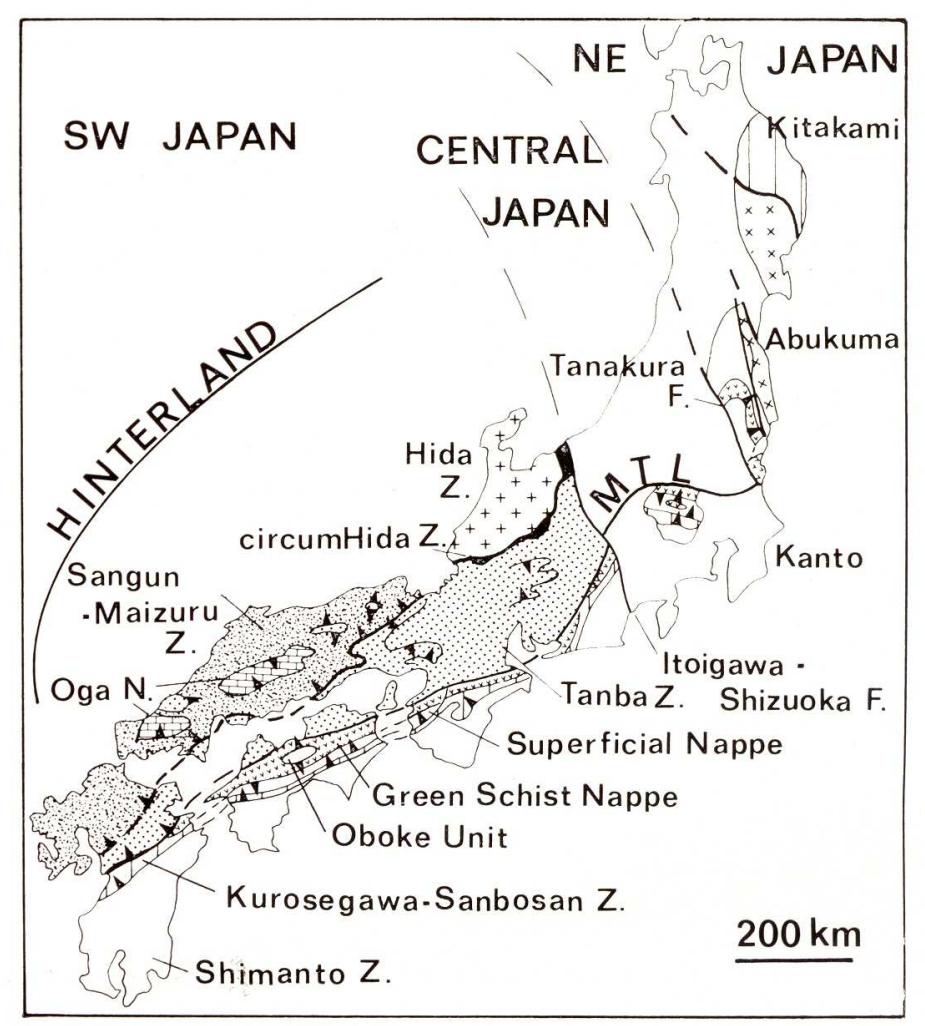

Fig. 1 


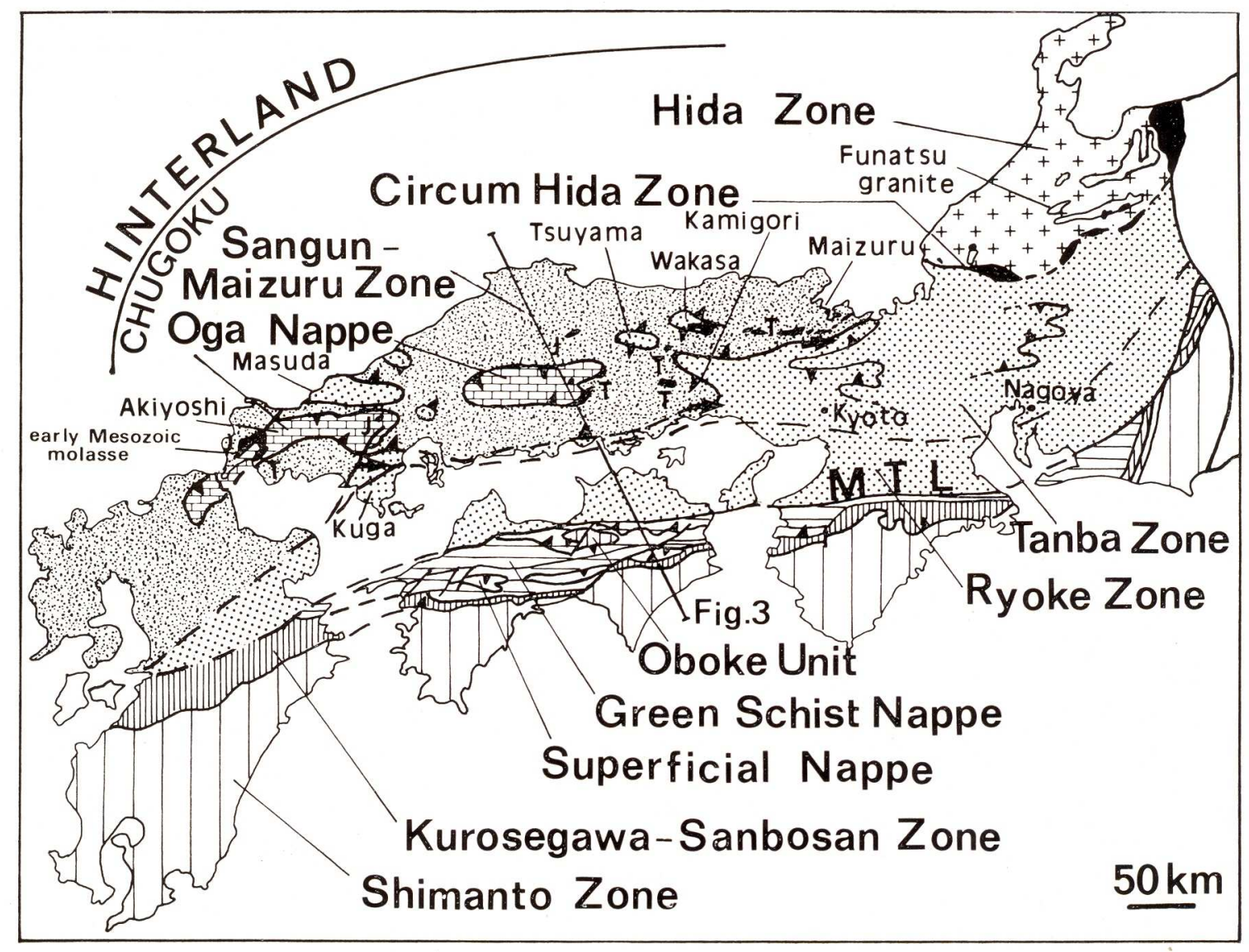

Fig. 2 

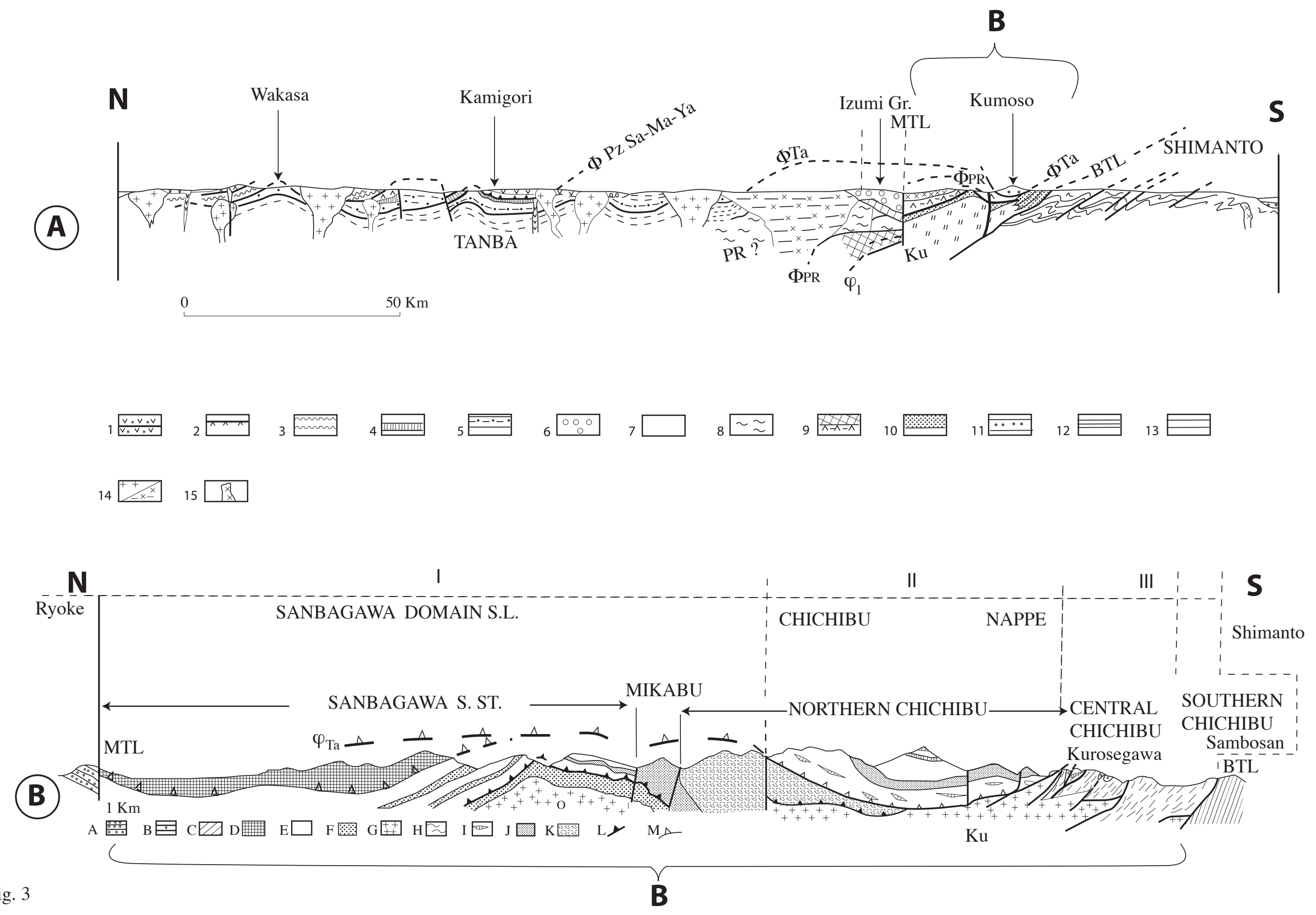


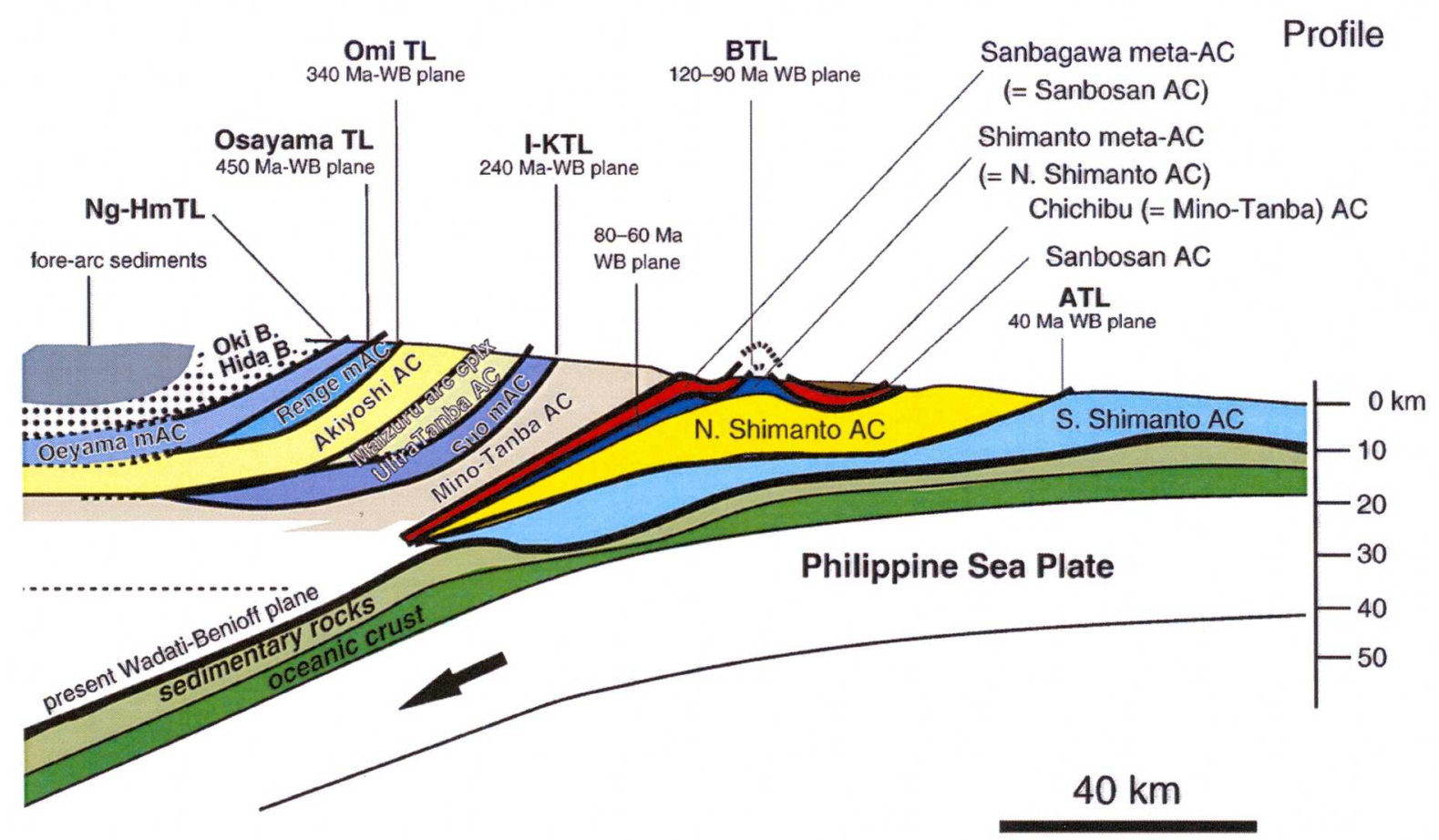

Fig. 4 


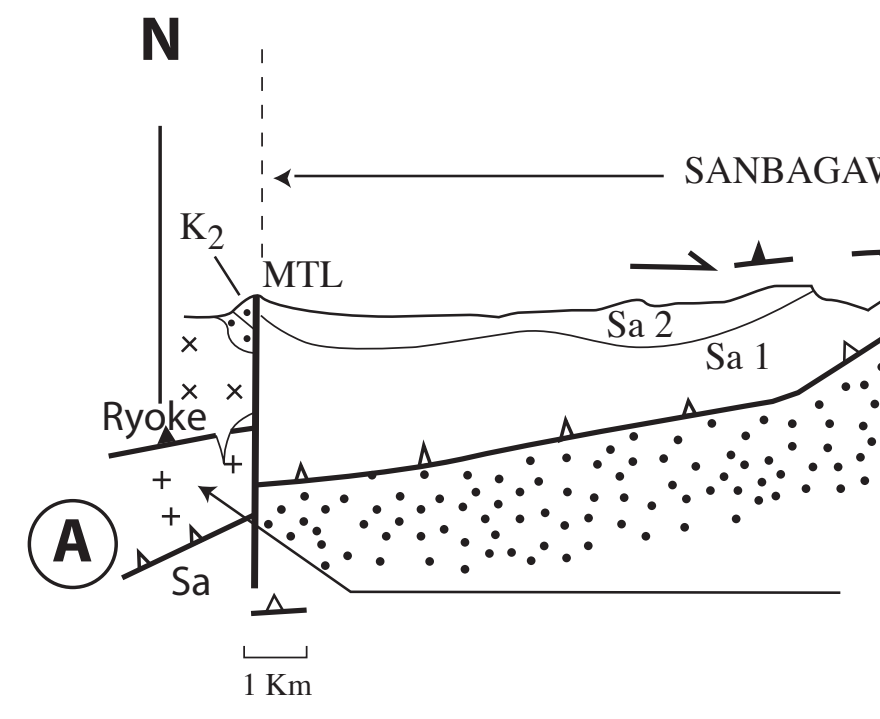

$\mathbf{N}$

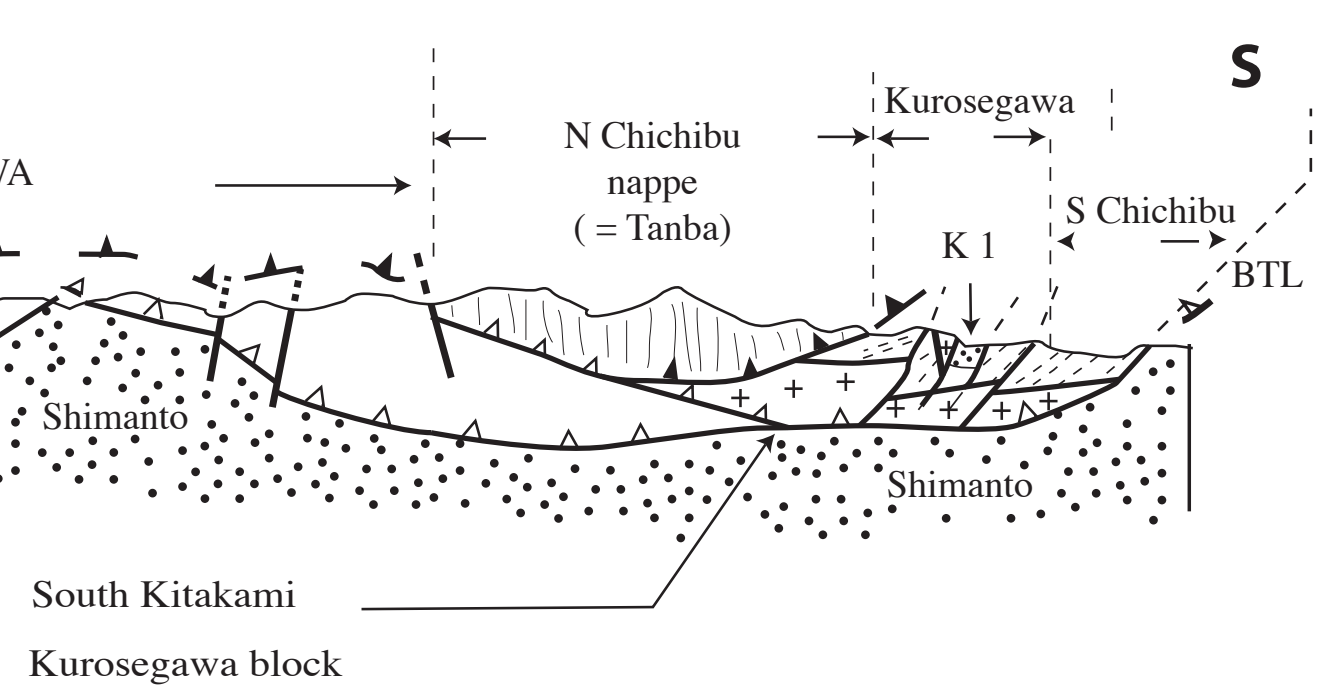

Chichibu Belt

(Jurassic accretionary complex)

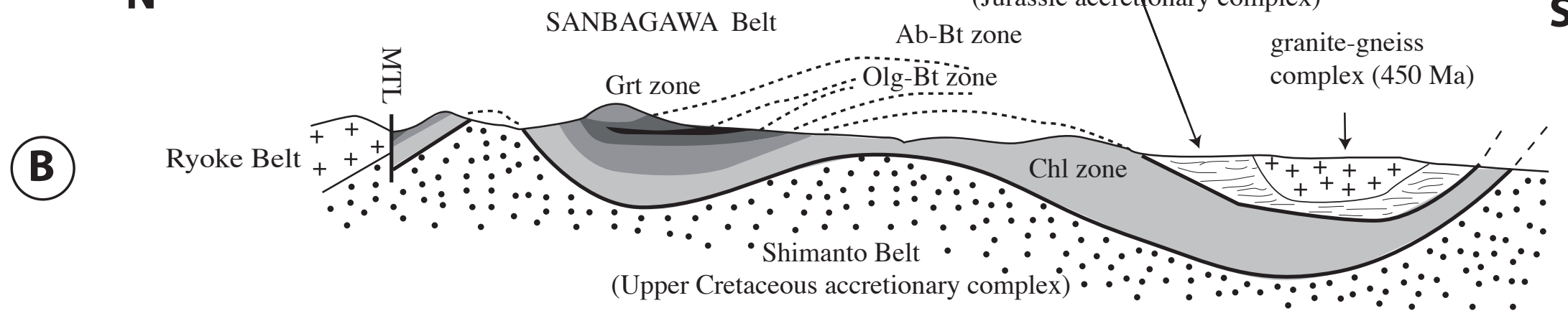




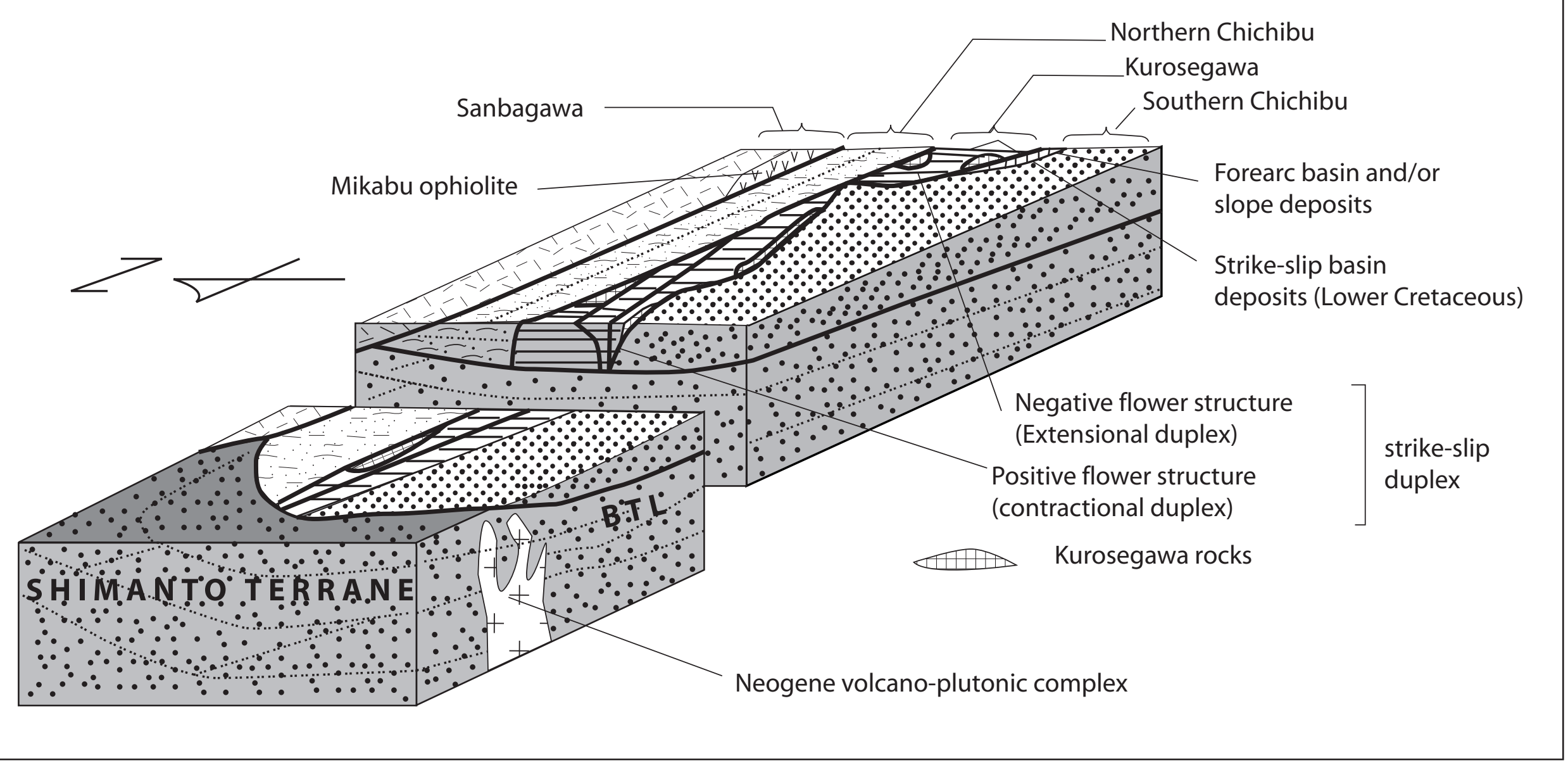


